Atmos. Chem. Phys., 17, 13699-13719, 2017

https://doi.org/10.5194/acp-17-13699-2017

(C) Author(s) 2017. This work is distributed under

the Creative Commons Attribution 3.0 License.

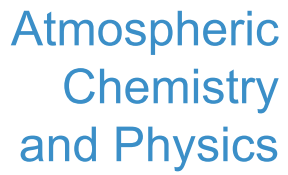

(c) (P)

\title{
Future inhibition of ecosystem productivity by increasing wildfire pollution over boreal North America
}

\author{
Xu Yue ${ }^{1,2}$, Susanna Strada ${ }^{3}$, Nadine Unger ${ }^{4}$, and Aihui Wang ${ }^{2}$ \\ ${ }^{1}$ Climate Change Research Center, Institute of Atmospheric Physics, Chinese Academy of Sciences, Beijing 100029, China \\ ${ }^{2}$ Nansen-Zhu International Research Centre, Institute of Atmospheric Physics, Chinese Academy of Sciences, \\ Beijing 100029, China \\ ${ }^{3}$ Laboratoire des Sciences du Climat et de l'Environnement, L'Orme des Merisiers - Bat 712, 91191 Gif-Sur-Yvette, France \\ ${ }^{4}$ College of Engineering, Mathematics and Physical Sciences, University of Exeter, Exeter, EX4 4QE, UK
}

Correspondence to: Xu Yue (xuyueseas@gmail.com)

Received: 5 April 2017 - Discussion started: 23 June 2017

Revised: 11 October 2017 - Accepted: 12 October 2017 - Published: 17 November 2017

\begin{abstract}
Biomass burning is an important source of tropospheric ozone $\left(\mathrm{O}_{3}\right)$ and aerosols. These air pollutants can affect vegetation photosynthesis through stomatal uptake (for $\mathrm{O}_{3}$ ) and light scattering and absorption (for aerosols). Wildfire area burned is projected to increase significantly in boreal North America by the mid-century, while little is known about the impacts of enhanced emissions on the terrestrial carbon budget. Here, combining site-level and satellite observations and a carbon-chemistry-climate model, we estimate the impacts of fire emitted $\mathrm{O}_{3}$ and aerosols on net primary productivity (NPP) over boreal North America. Fire emissions are calculated based on an ensemble projection from 13 climate models. In the present day, wildfire enhances surface $\mathrm{O}_{3}$ by $2 \mathrm{ppbv}(7 \%)$ and aerosol optical depth (AOD) at $550 \mathrm{~nm}$ by $0.03(26 \%)$ in the summer. By mid-century, area burned is predicted to increase by $66 \%$ in boreal North America, contributing more $\mathrm{O}_{3}(13 \%)$ and aerosols (37\%). Fire $\mathrm{O}_{3}$ causes negligible impacts on NPP because ambient $\mathrm{O}_{3}$ concentration (with fire contributions) is below the damage threshold of $40 \mathrm{ppbv}$ for $90 \%$ summer days. Fire aerosols reduce surface solar radiation but enhance atmospheric absorption, resulting in enhanced air stability and intensified regional drought. The domain of this drying is confined to the north in the present day but extends southward by 2050 due to increased fire emissions. Consequently, wildfire aerosols enhance NPP by $72 \mathrm{TgC}^{-1}$ in the present day but decrease NPP by $118 \mathrm{TgC} \mathrm{yr}^{-1}$ in the future, mainly because of the soil moisture perturbations. Our results suggest that future wildfire may accelerate boreal carbon loss, not only through
\end{abstract}

direct emissions increasing from $68 \mathrm{Tg} \mathrm{C} \mathrm{yr}^{-1}$ at present day to $130 \mathrm{Tg} \mathrm{Cyr}^{-1}$ by mid-century but also through the biophysical impacts of fire aerosols.

\section{Introduction}

The area burned by wildfire is increasing in recent decades in North American boreal regions (Stocks et al., 2002; Kasischke and Turetsky, 2006). Fire activity is closely related to weather conditions and large-scale atmospheric oscillations (Gillett et al., 2004; Duffy et al., 2005) and is projected to increase significantly in the future due to climatic changes (Flannigan et al., 2005; Balshi et al., 2009; de Groot et al., 2013; Wang et al., 2015). More area burned and the consequent fire emissions are accelerating carbon loss in boreal North America (Bond-Lamberty et al., 2007; Turetsky et al., 2011). Meanwhile, fire-induced air pollution, including ozone $\left(\mathrm{O}_{3}\right)$ and aerosols, is predicted to increase in boreal and downwind regions by mid-century (Yue et al., 2013, 2015). Wildfire emissions have large impacts on air quality (Wotawa and Trainer, 2000; Morris et al., 2006), weather and climate conditions (Randerson et al., 2006; Zhao et al., 2014), and public health ( $\mathrm{Zu}$ et al., 2016; Liu et al., 2017). However, little is known about how these pollutants affect ecosystem carbon assimilation and how this impact will change with the increased wildfire activity in the future. 
Surface $\mathrm{O}_{3}$ causes damages to photosynthesis through stomatal uptake (Sitch et al., 2007). In the present climate state, fire-induced $\mathrm{O}_{3}$ enhancements are predicted to reduce net primary productivity (NPP) in the Amazon forest by $230 \mathrm{Tg} \mathrm{Cyr}^{-1}\left(1 \mathrm{Tg}=10^{12} \mathrm{~g}\right)$, a magnitude comparable to the direct release of $\mathrm{CO}_{2}$ from fires in South America (Pacifico et al., 2015). The aerosol effects are more uncertain because both positive and negative feedbacks occur. Appearance of aerosols increases diffuse light, which is beneficial for shaded leaves in the lower canopy. Consequently, photosynthesis of the whole ecosystem will increase as long as the total light availability is not compromised (Kanniah et al., 2012). Rap et al. (2015) estimated that biomass burning aerosols increase Amazon NPP by $78-156 \mathrm{Tg} \mathrm{C} \mathrm{yr}^{-1}$, which offsets about half of the damage caused by fire $\mathrm{O}_{3}$ (Pacifico et al., 2015). In contrast, strong light attenuation associated with high aerosol loading may decrease canopy photosynthesis (Cohan et al., 2002; Oliveira et al., 2007; Cirino et al., 2014). Furthermore, the aerosol radiative effects indirectly influence ecosystem productivity through concomitant meteorological perturbations that are only beginning to be examined (Yue et al., 2017).

Future wildfire activity is projected to increase over boreal North America but with large uncertainties (Flannigan et al., 2005; Tymstra et al., 2007; Girardin and Mudelsee, 2008; Nitschke and Innes, 2008; Amiro et al., 2009; Balshi et al., 2009; Bergeron et al., 2010; Wotton et al., 2010; de Groot et al., 2013; Wang et al., 2016). For example, Amiro et al. (2009) predicted an increase of $34 \%$ in the area burned in Canada for a $2 \times \mathrm{CO}_{2}$ scenario (2040-2060) relative to a $1 \times \mathrm{CO}_{2}$ condition (1975-1995), using the Canadian Fire Weather Index (CFWI) and output from the Canadian Global Climate Model (CGCM) version 1. Balshi et al. (2009) projected that area burned in boreal North America would double by the year 2045-2050 relative to 1991-2000, using the Multivariate Adaptive Regression Splines (MARS) approach and meteorological output from CGCM version 2. The increasing rate in Balshi et al. (2009) is higher than that in Amiro et al. (2009), indicating substantial uncertainties in fire projections originating from both fire models and simulated future climate. However, even with the same fire models and climate change scenario, large uncertainties (in both magnitude and signs) are found in the projection of area burned among individual climate models (Moritz et al., 2012; Yue et al., 2013). The multi-model ensemble approach has shown superior predictability over single models in historical climate simulations (Flato et al., 2013) and near-term climate predictions (Kirtman et al., 2014) and has been used as a standard technique to assess changes of climate variables in the long-term projections (Collins et al., 2013). Following this strategy, Yue et al. (2015) used output from 13 climate models to drive fire regression models and predicted an average increase of $66 \%$ in boreal area burned at 20462065 relative to 1981-2000 under the IPCC A1B scenario (Solomon et al., 2007). Yue et al. (2015) further calculated

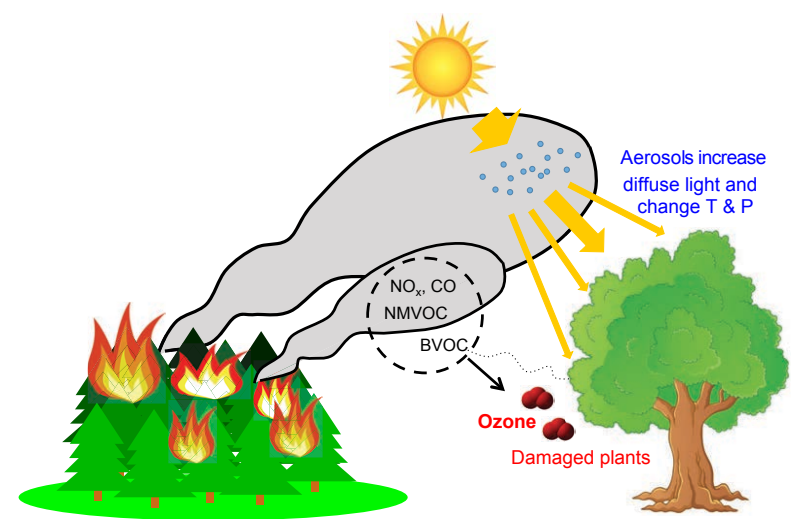

Figure 1. Illustration of atmospheric chemistry and physics as well as biospheric processes investigated in the study. Carbonaceous aerosols from fire plumes increase diffuse light and change temperature $(\mathrm{T})$ and precipitation $(\mathrm{P})$, influencing vegetation photosynthesis. Ozone generated photochemically from fire-emitted precursors $\left(\mathrm{NO}_{x}, \mathrm{CO}\right.$, and non-methane volatile organic compounds, NMVOC) and associated biogenic volatile organic compound (BVOC) changes causes direct damage to plant photosynthesis.

that the wildfire emission increase by the 2050s would increase mean summertime surface $\mathrm{O}_{3}$ by 5 ppbv in Alaska and 3 ppbv in Canada. The study found regional maximum $\mathrm{O}_{3}$ enhancements as high as $15 \mathrm{ppbv}$, suggesting the potential for possible vegetation damage and land carbon loss due to the enhanced boreal fire-related air pollution. Wildfire aerosols are also expected to increase significantly but not predicted in Yue et al. (2015).

In this study, we quantify the impacts of $\mathrm{O}_{3}$ and aerosols emitted from boreal wildfires on the land carbon uptake in North America in the present climate state and in the future world at 2050, taking advantage of the ensemble projection of future wildfire emissions by Yue et al. (2015). The major chain we investigate includes (i) generation of aerosols and surface ozone from wildfire emissions and (ii) impact of fireemitted aerosols and ozone on plant photosynthesis through physical and biogeochemical processes (Fig. 1). We first analyze relationships between gross primary production (GPP) and aerosol optical depth (AOD) at $550 \mathrm{~nm}$ over the boreal regions based on observations. We then perform a suite of Earth system model simulations using NASA GISS ModelE2 that embeds the Yale Interactive Terrestrial Biosphere model (YIBs), a framework known as ModelE2-YIBs (Yue and Unger, 2015). Future projections of wildfire emissions from Yue et al. (2015) are applied as input to ModelE2-YIBs model to project fire-induced $\mathrm{O}_{3}$ and aerosol concentrations in the 2010s and 2050s. The impacts of the boreal fire $\mathrm{O}_{3}$ on forest photosynthesis are predicted using the flux-based damage algorithm proposed by Sitch et al. (2007), which has been fully evaluated against available $\mathrm{O}_{3}$ damage sensitivity measurements globally and over North America (Yue and 
Unger, 2014; Yue et al., 2016, 2017). Fire aerosols induce perturbations to radiation, meteorology, and hydrology, leading to multiple influences on the land carbon uptake. Sensitivity experiments are performed using the YIBs model in offline mode to isolate the contributions of changes in the individual meteorological drivers.

\section{Materials and methods}

\subsection{Observed GPP-AOD relationships}

Following the approach by Strada et al. (2015), we investigate the GPP sensitivity to diffuse radiation and AOD variability in boreal regions. First, we identify study sites in Canada and Alaska from the AmeriFlux (AMF) network (http://ameriflux.lbl.gov/). There are much fewer boreal sites than those in temperate regions. We select AMF sites providing hourly (or half-hourly) simultaneous measurements of GPP (non-gap-filled) and photosynthetically active radiation (PAR, total and diffuse) for at least 3 consecutive years. Only two Canadian sites meet the criteria: Groundhog River (CA-Gro; $82.2^{\circ} \mathrm{W}, 48.2^{\circ} \mathrm{N}$ ), a mixed forest (MF), and Québec Mature Boreal Forest Site (CA-Qfo; $73.4^{\circ} \mathrm{W}$, $49.7^{\circ} \mathrm{N}$ ), an evergreen needleleaf forest (ENF). At the two selected sites, we calculate the Pearson's correlation coefficients between half-hourly GPP and different components of PAR. In total, we select 2432 and 3201 pairs of GPP and PAR measurements at CA-Gro and CA-Qfo, respectively. We then apply instantaneous Level 2 Collection 6 of AOD pixels at $3 \mathrm{~km}$ resolution retrieved by the Moderate Resolution Imaging Spectroradiometer (MODIS, https: //ladsweb.nascom.nasa.gov/) onboard the Aqua and Terra satellites (Levy et al., 2013). The MODIS $3 \mathrm{~km}$ AOD product has been fully validated against ground-based sun photometers on both global (Remer et al., 2013) and urban/suburban (Munchak et al., 2013) scales. Strada et al. (2015) used ground-based AOD observations from the Aerosol Robotic Network (AERONET) near AMF sites to validate the sampling technique of MODIS $3 \mathrm{~km}$ AOD product. They found high correlations of $0.89-0.98$ and regression slopes from 0.89 to 1.03 for daily AOD between AERONET and MODIS at four AMF sites. For this study, the validation against ground-based AOD observations was not possible because no AERONET stations exist near to the selected AMF sites.

Every day, MODIS satellite sensors pass a specific region between 10:00 and 14:00 local time (LT), leaving patchy signals around the AMF sites. Most of MODIS AOD data at high latitudes are available only in boreal summer; as a result, we narrow our explorations of the GPP-AOD relationships to the noontime (10:00-14:00 LT) from June to August. The chosen noontime window limits the contributions that confounding factors such as low solar angles and high diffuse fraction may have on the amount of diffuse PAR and plant productivity (Niyogi et al., 2004). For each sum- mer day, we select instantaneous MODIS $3 \mathrm{~km}$ AOD pixels that are (a) located within a distance of $0.03^{\circ}$ (about $3 \mathrm{~km}$ ) from the targeted AMF site and (b) "quasi-coincident" with AMF data, which are available each half-hour. Because of the unavoidable temporal differences between MODIS overpass and AMF data availability, we name this selection quasicoincident. A cloud mask applied to the MODIS retrieval procedure conveniently filters out cloudy instants and should reduce the effect of clouds in the scattering process. We calculate both the correlation and regression coefficients between quasi-coincident GPP and AOD at the selected sites. Negative GPP is considered as a missing value. To further reduce the influence of cloud cover, we discard instants (both AMF and MODIS data) when precipitation is nonzero. In total, we select 65 pairs of GPP and AOD at CA-Gro site and another 59 pairs at CA-Qfo site. The GPP-AOD sampling pairs are much fewer than GPP-PAR, because we select instants when both instantaneous AOD and GPP data are available. In addition, AOD is screened for clear instants to exclude the impacts of clouds.

\subsection{Wildfire emissions}

Wildfire emissions used in climate modeling are calculated as the product of area burned, fuel consumption, and emission factors. To predict area burned, we build stepwise regressions for area burned in 12 boreal ecoregions (Yue et al., 2015). Observed area burned aggregated from interagency fire reports is used as the predictand. Predictors are selected from $44(5 \times 6+7 \times 2)$ variables including five meteorological parameters (mean and maximum temperature, relative humidity, precipitation, and geopotential height at $500 \mathrm{hPa}$ ) of six different time intervals (winter, spring, summer, autumn, fire season (May-October), and the whole year), as well as the mean and maximum values of 7 fire indexes from the CFWI system during fire season. We consider the impacts of antecedent factors on current fire activity by including all above variables at the same year and those in the previous 2 years, making a total of $132(44 \times 3)$ factors. The final formats of regression are different among ecoregions, depending on the selection of the factors that contribute the maximum observed variance in predictands but remain the minimum collinearity among predictors. These regression functions are then driven with output from $13 \mathrm{Cou}-$ pled Model Intercomparison Project Phase 3 (CMIP3) climate models under the A1B scenario (Meehl et al., 2007) to predict area burned at present day (1981-2000) and midcentury (2046-2065). In the A1B scenario, $\mathrm{CO}_{2}$ concentration is projected to $532 \mathrm{ppm}$ by the year 2050, similar to the value of $541 \mathrm{ppm}$ in the IPCC RCP8.5 scenario (van Vuuren et al., 2011) archived for the Coupled Model Intercomparison Project Phase 5 (CMIP5).

We derive a $1^{\circ} \times 1^{\circ}$ gridded burned area based on the prediction for each ecoregion following the approach by Yue et al. (2015). Temporally, the annual area burned estimated with 
regressions is first converted to monthly area burned using the mean seasonality for each boreal ecoregion during 19802009. Spatially, large fires tend to burn in ecosystems where historical fires are frequent because of favorable conditions (Keane et al., 2008). In each $1^{\circ} \times 1^{\circ}$ grid square, we calculate the frequency of large fires (>1000 ha) during 19802009; these fires account for about $85 \%$ of total area burned in boreal North America. We arbitrarily attribute $85 \%$ of area burned within each ecoregion to a number of fires with fixed size of $1000 \mathrm{ha}$. We then allocate these large fires among the $1^{\circ} \times 1^{\circ}$ grid cells based on the observed spatial probability of large fires. For example, if one grid box (named grid A) bears $1 \%$ of large fires $(>1000 \mathrm{ha})$ within an ecoregion at present day, the same grid will bear the same possibility for large fires in the future. However, fuel availability limits reburning and fire spread during the forest return interval, suggesting that current burning will decrease the possibility of future fires in the same location. To consider such impact, we scale the observed probabilities by the fraction remaining unburned in each grid box and then use this modified probability distribution to allocate large fires for the remaining months. For example, if present-day fires have consumed $20 \%$ of the total area within grid A, then the possibility of large fire will be $0.8 \%(1 \% \times 0.8$, instead of $1 \%)$ for this grid. Finally, we disaggregate the remaining $15 \%$ of area burned into fires 10 ha in size and randomly distribute these fires across all grid boxes in the ecoregion. With this method, we derive the gridded area burned for boreal North America by eliminating reburning issues. Sensitivity tests show that specifying different area burned to the large fires (100 or 10000 ha rather than $1000 \mathrm{ha}$ ) yields $<1 \%$ changes in predicted biomass burned, suggesting that this approach is not sensitive to the presumed fire size in the allocation procedure.

Fuel consumption, the dry mass burned (DM) per fire area, is the product of fuel load and burning severity. For fuel load in Alaska, we use $1 \mathrm{~km}$ inventory from the US Forest Service (USFS) Fuel Characteristic Classification System (FCCS; McKenzie et al., 2007). For fuel load in Canada, we use a $1 \mathrm{~km}$ fuel type map from the Canadian Fire Behavior Prediction (FBP) system (Nadeau et al., 2005), combined with fuel-bed definition from the FCCS. Burning severity, the fraction of fuel load burned by fires, is calculated with the USFS CONSUME model 3.0 following the approach described in Val Martin et al. (2012). With both fuel load and burning severity, we derive fuel consumption and further calculate biomass burned in boreal North America with the predicted area burned. As in Amiro et al. (2009) and Yue et al. (2015), we apply constant fuel load for both present day and mid-century because opposite and uncertain factors influence future projections (Kurz et al., 2008; Heyder et al., 2011; Friend et al., 2014; Knorr et al., 2016; Kim et al., 2017). Instead, we consider changes in burning severity due to perturbations in fuel moisture as indicated by CFWI (Yue et al., 2015). On average, we estimate a $9 \%$ increase in fuel consumption over boreal North America by the midcentury, because higher temperature and lower precipitation result in a future with drier fuel load (Flannigan et al., 2016).

Fire emissions for a specific species are then estimated as the product between biomass burned and the corresponding emission factor, which is adopted from measurements by Andreae and Merlet (2001) except for $\mathrm{NO}_{x}$. We use the average value of $1.6 \mathrm{~g} \mathrm{NO}$ per $\mathrm{kg} \mathrm{DM}$ from six studies as $\mathrm{NO}_{x}$ emission factor, because the number of $3.0 \mathrm{~g} \mathrm{NO}$ per $\mathrm{kg}$ DM reported in Andreae and Merlet (2001) is much higher than that of $1.1 \mathrm{~g} \mathrm{NO}$ per $\mathrm{kg}$ DM from field observations (Alvarado et al., 2010). Based on projected area burned and observationbased fuel consumption and emission factors, we derive fire emissions of $\mathrm{NO}_{x}$, carbon monoxide (CO), non-methane volatile organic compounds (NMVOCs, alkenes, and alkanes), $\mathrm{NH}_{3}, \mathrm{SO}_{2}$, black carbon (BC), and organic carbon (OC) in the present day and mid-century.

\subsection{NASA ModelE2-YIBs model}

The NASA ModelE2-YIBs is an interactive climate-carbonchemistry model, which couples the chemistry-climate model NASA ModelE2 (Schmidt et al., 2014) and the YIBs vegetation model (Yue and Unger, 2015). NASA ModelE2 is a general circulation model with horizontal resolution of $2^{\circ} \times 2.5^{\circ}$ latitude by longitude and 40 vertical layers up to $0.1 \mathrm{hPa}$. It dynamically simulates both the physical (emissions, transport, and deposition) and chemical (production, conversion, and loss) processes of gas-phase chemistry $\left(\mathrm{NO}_{x}, \mathrm{HO}_{x}, \mathrm{O}_{x}, \mathrm{CO}, \mathrm{CH}_{4}\right.$, and $\left.\mathrm{NMVOCs}\right)$, aerosols (sulfate, nitrate, ammonium, BC, OC, dust, and sea salt), and their interactions. In the model, oxidants influence the photochemical formation of secondary aerosol species (e.g., sulfate, nitrate, and biogenic secondary organic aerosol), in turn, aerosols alter photolysis rates and influence the online gas-phase chemistry. Size-dependent optical parameters computed from Mie scattering, including extinction coefficient, single scattering albedo, and asymmetry parameters, are applied for each aerosol type (Schmidt et al., 2014). The model also considers interactions between climate and atmospheric components. Simulated climate affects formation, transport, and deposition of atmospheric components, in turn, both $\mathrm{O}_{3}$ and aerosols influence climate by altering radiation, temperature, precipitation, and other climatic variables. Both observation-based evaluations and multi-model intercomparisons indicate that ModelE2 demonstrates skill in simulating climatology (Schmidt et al., 2014), soil moisture (Fig. S1 in the Supplement), radiation (Wild et al., 2013), atmospheric composition (Shindell et al., 2013b), and radiative effects (Shindell et al., 2013a).

YIBs is a process-based vegetation model that dynamically simulates changes in leaf area index (LAI) through carbon assimilation, respiration, and allocation for prescribed plant functional types (PFTs). Coupled photosynthesisstomatal conductance is simulated with the Farquhar-Ball- 
Table 1. Online simulations with ModelE2-YIBs climate model.*

\begin{tabular}{lrrrrrr}
\hline Simulations & SST & {$\left[\mathrm{CO}_{2}\right]$} & Emissions & Fires & $\mathrm{O}_{3}$ effect & Aerosol effect \\
\hline F10O3 & $2010 \mathrm{~s}$ & $2010 \mathrm{~s}$ & $2010 \mathrm{~s}$ & $2010 \mathrm{~s}$ & Yes & No \\
F10AERO & $2010 \mathrm{~s}$ & $2010 \mathrm{~s}$ & $2010 \mathrm{~s}$ & $2010 \mathrm{~s}$ & No & Yes \\
F10CTRL & $2010 \mathrm{~s}$ & $2010 \mathrm{~s}$ & $2010 \mathrm{~s}$ & No & No & Yes \\
F50O3 & $2050 \mathrm{~s}$ & $2050 \mathrm{~s}$ & $2050 \mathrm{~s}$ & $2050 \mathrm{~s}$ & Yes & No \\
F50AERO & $2050 \mathrm{~s}$ & $2050 \mathrm{~s}$ & $2050 \mathrm{~s}$ & $2050 \mathrm{~s}$ & No & Yes \\
F50CTRL & $2050 \mathrm{~s}$ & $2050 \mathrm{~s}$ & $2050 \mathrm{~s}$ & No & No & Yes \\
\hline
\end{tabular}

* Values of SST, $\left[\mathrm{CO}_{2}\right]$, and emissions are adopted from RCP8.5 scenario, with the average of 2006-2015 for the 2010s and that of 2046-2055 for the 2050s. For fire emissions, 2010 values are predicted based on meteorology for 1981-2000 and 2050 values are for 2046-2065.

Berry scheme (Farquhar et al., 1980; Ball et al., 1987). Leaflevel photosynthesis is upscaled to canopy level by separating diffuse and direct light for sunlit and shaded leaves (Spitters, 1986). Plant respiration considers thermal dependence as well as acclimation to temperature (Atkin and Tjoelker, 2003). Soil respiration is calculated based on the carbon flows among 12 biogeochemical pools (Schaefer et al., 2008). Net carbon uptake is allocated among leaves, stems, and roots to support leaf development and plant growth (Cox, 2001). The YIBs model has been benchmarked against in situ GPP from 145 eddy covariance flux tower sites and satellite retrievals of LAI and phenology (Yue and Unger, 2015). An interactive flux-based $\mathrm{O}_{3}$ damage scheme proposed by Sitch et al. (2007) is applied to quantify the photosynthetic responses to ambient $\mathrm{O}_{3}$ (Yue and Unger, 2014). For this scheme, $\mathrm{O}_{3}$ damaging level is dependent on excess $\mathrm{O}_{3}$ stomatal flux within leaves, which is a function of ambient $\mathrm{O}_{3}$ concentration, boundary layer resistance, and stomatal resistance. Reduction of photosynthesis is calculated on the basis of PFTs, each of which bears a range of low-to-high sensitivities to $\mathrm{O}_{3}$ uptake.

\subsection{Simulations}

Using the NASA ModelE2-YIBs model, we perform six time-slice simulations, three for present-day (2010s) and three for mid-century (2050s), with atmosphere-only configuration to explore the impacts of fire emissions on NPP in boreal North America (Table 1). Simulations F10CTRL and F50CTRL turn off all fire emissions as well as $\mathrm{O}_{3}$ vegetation damage for the 2010s and 2050s, respectively. However, climatic feedbacks of aerosols from other sources (both natural and anthropogenic) and related photosynthetic responses are included. Simulations F10AERO and F50AERO consider the responses of plant productivity to perturbations in radiation and meteorology caused by aerosols, including emissions from wildfires and other sources, but do not include any $\mathrm{O}_{3}$ vegetation damage. In contrast, simulations $\mathrm{F} 10 \mathrm{O} 3$ and $\mathrm{F} 50 \mathrm{O} 3$ calculate offline $\mathrm{O}_{3}$ damage based on the simulated $\mathrm{O}_{3}$ from all sources including fire emissions. For these simulations, reductions of GPP are calculated twice with ei- ther low or high $\mathrm{O}_{3}$ sensitivity. However, both of these GPP changes are not fed back into the model to influence carbon allocation and tree growth. Plant respiration is changing in response to meteorological perturbations due either to climate change or to aerosol radiative effects. We assume no impact of $\mathrm{O}_{3}$ damage to plant respiration and examine vegetation NPP, the net carbon uptake by biosphere, for the current study. The difference between AERO and CTRL runs isolates the impacts of fire aerosols on NPP, and the difference between $\mathrm{O} 3$ and CTRL runs isolates $\mathrm{O}_{3}$ vegetation damage caused by fire and non-fire emission sources.

All simulations are conducted for 20 years and outputs for the last 15 years are used for analyses. The simulations apply sea surface temperatures (SSTs) and sea ice distributions from previous NASA GISS experiments under the IPCC RCP8.5 scenario (van Vuuren et al., 2011). Decadal average monthly-varying SST and sea ice of 2006-2015 are used as boundary conditions for present-day (2010s) runs while that of 2046-2055 are used for future (2050s) runs. In the RCP8.5 scenario, global average SST increases by $0.62^{\circ} \mathrm{C}$ while sea ice area decreases by $13.8 \%$ at the mid-century compared to the present-day level. Decadal average well-mixed greenhouse gas concentrations and anthropogenic emissions of short-lived species, both at present day and mid-century, are adopted from the RCP8.5 scenario (Table 2). The enhancement of $\mathrm{CO}_{2}$ will affect climate (through longwave absorption) and ecosystem productivity (through $\mathrm{CO}_{2}$ fertilization) but not the fire activity and related emissions directly. Natural emissions of soil and lightning $\mathrm{NO}_{x}$, biogenic volatile organic compounds (BVOCs), dust, and sea salt are climate sensitive and simulated interactively. The YIBs vegetation model cannot simulates changes in PFT fractions. The RCP8.5 land cover change dataset shows limited changes in land cover fractions between the 2010s and 2050s (Oleson et al., 2010). For example, relative to the 2010s, a maximum gain of $5 \%$ is predicted for grassland in the 2050s, resulting from a $1 \%$ loss in deciduous forest and another $1 \%$ loss in needleleaf forest over boreal North America. As a result, a land cover dataset derived from satellite retrievals (Hansen et al., 2003) is applied as boundary conditions for both the 2010s and 2050s. 
Table 2. Emissions from wildfires and non-fire sources over boreal North America.

\begin{tabular}{lccccr}
\hline Species & \multicolumn{2}{c}{$\begin{array}{c}\text { Fire emissions } \\
\left(\mathrm{Tg} \mathrm{yr}^{-1}\right)\end{array}$} & & \multicolumn{2}{c}{$\begin{array}{c}\text { Non-fire emissions } \\
\left(\mathrm{Tg} \mathrm{yr}^{-1}\right)\end{array}$} \\
\cline { 2 - 3 } \cline { 5 - 6 } & $2010 \mathrm{~s}$ & $2050 \mathrm{~s}$ & & $2010 \mathrm{~s}$ & $2050 \mathrm{~s}$ \\
\hline $\mathrm{NO}_{x}^{\mathrm{a}}$ & 0.39 & 0.74 & & 2.43 & 2.08 \\
$\mathrm{CO}$ & 15.7 & 28.8 & & 5.9 & 4.0 \\
$\mathrm{SO}_{2}^{\mathrm{a}}$ & 0.12 & 0.22 & & 1.95 & 1.28 \\
$\mathrm{NH}_{3}$ & 0.22 & 0.40 & & 0.80 & 1.15 \\
$\mathrm{BC}$ & 0.08 & 0.16 & & 0.03 & 0.01 \\
$\mathrm{OC}$ & 1.10 & 2.04 & & 0.04 & 0.02 \\
$\mathrm{NMVOC}$ & 0.39 & 1.34 & & 0.49 & 0.30 \\
$\mathrm{BVOC}^{\mathrm{b}}$ & $\mathrm{NA}$ & $\mathrm{NA}$ & & 15.3 & 15.1 \\
\hline
\end{tabular}

a Natural emissions are included for $\mathrm{NO}_{x}$ (lightning and soil) and $\mathrm{SO}_{2}$ (volcano).

${ }^{\mathrm{b}}$ ModelE2-YIBs calculates BVOC emissions using photosynthesis-dependent

scheme implemented by Unger et al. (2013).

To evaluate the simulated GPP responses to changes in diffuse radiation, we perform site-level simulations using the stand-alone YIBs model, which is driven with observed hourly meteorology (including temperature, relative humidity, surface pressure, wind speed, and soil moisture) and both diffuse and direct PAR at sites CA-Gro and CA-Qfo. To isolate the impact of individual aerosol-induced climatic perturbations on NPP, we perform 10 sensitivity experiments using the offline YIBs model driven with offline meteorology simulated by ModelE2-YIBs model (Table 3). For example, the offline run Y10_CTRL is driven with variables from the online simulation of F10CTRL (Table 1). The run Y10_TAS adopts the same forcing as Y10_CTRL except for temperature, which is simulated by the climate simulation of F10AERO. In this case, we quantify the NPP responses to individual and/or combined climate feedback (mainly in temperature, radiation, and soil moisture) by fire aerosols. Each offline run is conducted for 12 years and the last 10 years are used for analyses.

\subsection{Observation datasets}

We use observations to evaluated GPP, AOD, and $\mathrm{O}_{3}$ in boreal North America simulated by ModelE2-YIBs. For GPP, we use a benchmark data product upscaled from FLUXNET eddy covariance data using an ensemble of regression trees (Jung et al., 2009). For AOD observations, we use satellite retrieval at $550 \mathrm{~nm}$ from Terra MODIS Level 3 data product. For $\mathrm{O}_{3}$, gridded datasets are not available. We use site-level observations from 81 US sites at the Clean Air Status and Trends Network (CASTNET, https://www.epa.gov/castnet) and 202 Canadian sites at the National Air Pollution Surveillance (NAPS, http://www.ec.gc.ca/rnspa-naps/) program. All datasets are averaged over the 2008-2012 period to represent present-day climatological conditions. Gridded datasets are interpolated to the same $2^{\circ} \times 2.5^{\circ}$ resolution as ModelE2YIBs model.

\section{Results}

\subsection{Observed GPP-AOD relationships}

Positive correlations between GPP and diffuse PAR are found at the two boreal sites (Fig. 2b, c). The magnitude of diffuse PAR is similar for these sites, possibly because they are located at similar latitudes (Fig. 2a). GPP values at CAGro are generally higher than that at CA-Qfo, likely because deciduous broadleaf forest (DBF) has higher photosynthetic rates. Consequently, the slope of regression between GPP and $\mathrm{PAR}_{\text {dif }}$ is higher at CA-Gro than that at CA-Qfo, suggesting that GPP of DBF (or MF) is more sensitive to changes in diffuse PAR than that of ENF. We find almost zero correlation between GPP and PAR dir at the two sites (Table 4), indicating that photosynthesis is in general light-saturated for sunlit leaves at these sites during boreal summer noontime. As a result, modest reductions in direct light by aerosols will not decrease GPP of the whole canopy.

With satellite-based AOD, we find positive correlations between GPP and AOD at both sites (Fig. 2d, e). However, the slope of regression between GPP and AOD is lower (and not significant) at CA-Gro compared with that at CA-Qfo, opposite to the GPP-PAR ${ }_{\text {dif }}$ regressions. The cause of such discrepancy might be related to the limitation of data availability. For the same reason, the GPPAOD correlation is insignificant at CA-Gro site. On average, GPP sensitivity (denoted as mean \pm range) is estimated as $3.5 \pm 1.1 \mu \mathrm{molm} \mathrm{m}^{-2} \mathrm{~s}^{-1}$ per unit AOD at lower latitudes of boreal regions in the summer.

\subsection{Model evaluations}

Simulated summer GPP shows high values in mid-western Canada (Alberta and Saskatchewan) and the southeast (Ontario) (Fig. 3a). Forest GPP at high latitudes is low because of the cool weather and light limitation there. Simulated GPP reasonably captures the spatial distribution with a high correlation coefficient of $0.77(p \ll 0.01)$ and relatively small biases within $20 \%$ of the data product. Simulated AOD reproduces the observed spatial pattern including the high values in boreal forests (Fig. 3b). In contrast to the MODIS observations, predicted AOD is relatively uniform over the west with a background value of $\sim 0.1$. This discrepancy explains the low correlation coefficient $(R=0.25, p<0.01)$ between the model and MODIS data. The simulation fails to capture the high values in the west, possibly due to a climate model underestimation of biogenic secondary organic aerosol, which may be an important contribution over the western boreal forest. Simulated maximum daily $8 \mathrm{~h}$ average (MDA8) $\left[\mathrm{O}_{3}\right]$ shows low values in boreal North America and high values in the western and eastern US (Fig. 4a). This pattern is consis- 
Table 3. Simulations with YIBs vegetation model driven by offline meteorology from ModelE2-YIBs climate model.

\begin{tabular}{lllll}
\hline Simulations & Base forcing & Temperature & PAR & Soil moisture \\
\hline Y10_CTRL & F10CTRL & & & \\
Y10_ALL & F10CTRL & F10AERO & F10AERO & F10AERO \\
Y10_TAS & F10CTRL & F10AERO & & \\
Y10_PAR & F10CTRL & & F10AERO & \\
Y10_SLM & F10CTRL & & & F10AERO \\
Y50_CTRL & F50CTRL & & & \\
Y50_ALL & F50CTRL & F50AERO & F50AERO & F50AERO \\
Y50_TAS & F50CTRL & F50AERO & & \\
Y50_PAR & F50CTRL & & F50AERO & \\
Y50_SLM & F50CTRL & & & F50AERO \\
\hline
\end{tabular}
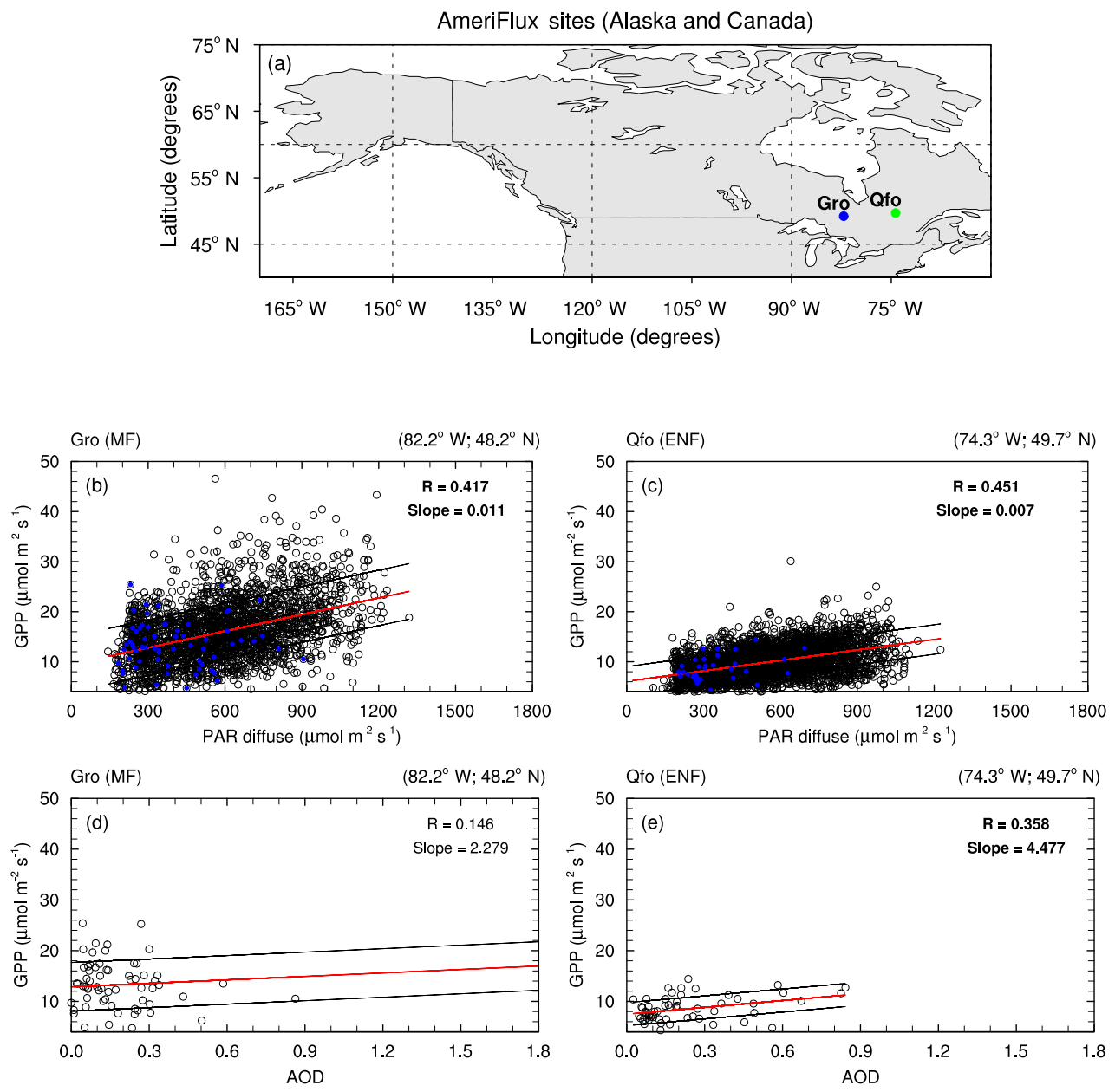

Figure 2. Relationships between (b, c) GPP and diffuse PAR and (d, e) GPP and MODIS AOD at (a) two boreal sites: Groundhog River (Gro) and Québec Mature Boreal Forest Site (Qfo). The two sites are from the AmeriFlux network in Canada and are dominated by mixed forest (MF at Gro) and evergreen needleleaf forest (ENF at Qfo) (Table 1). Data cover summer days (June-August). AmeriFlux diffuse PAR and GPP (in $\mu \mathrm{mol} \mathrm{m}{ }^{-2} \mathrm{~s}^{-1}$ ) are half-hourly observations (10:00-14:00 LT). Instantaneous MODIS Aqua and Terra $3 \mathrm{~km}$ AOD are selected in a time span centered on AmeriFlux record time. For each plot: the red line indicates the regression line and black lines depict the $1 \sigma$ interval; the regression slope and correlation coefficient are both included for each site (in bold if statistically significant at $95 \%$ confidence level). Blue dots in panels (b, c) show instants when MODIS Aqua and Terra $3 \mathrm{~km}$ AODs overlap AmeriFlux data. 
Table 4. Pearson's correlation coefficients for GPP-PAR and GPP-AOD relationships at AmeriFlux (AMF) sites ${ }^{\mathrm{a}}$.

\begin{tabular}{llrrrrrr}
\hline \multirow{2}{*}{ Site } & Period $^{\mathrm{b}}$ & \multicolumn{5}{c}{ Pearson's $R$} \\
\cline { 3 - 7 } & & GPP-PAR & GPP-PAR $_{\text {dir }}$ & GPP-PAR $_{\text {dif }}$ & GPP-AOD & AOD-PAR $_{\text {dif }}$ & AOD-PAR $_{\text {dir }}$ \\
\hline CA-Gro & $2004-2013$ & $\mathbf{0 . 1 9}(2432)$ & $-0.01(2432)$ & $\mathbf{0 . 4 2}(2432)$ & $0.15(65)$ & $\mathbf{0 . 6 0}(65)$ & $\mathbf{- 0 . 5 2}(65)$ \\
CA-Qfo & $2003-2014$ & $\mathbf{0 . 1 6}(3201)$ & $\mathbf{- 0 . 0 4}(3201)$ & $\mathbf{0 . 4 5}(3201)$ & $\mathbf{0 . 3 6}(59)$ & $\mathbf{0 . 9 1}(34)$ & $\mathbf{- 0 . 8 0}(34)$ \\
\hline
\end{tabular}

a Both GPP and PAR (direct PAR dir $_{\text {and diffuse }}$ PAR $_{\text {dif }}$ ) data are adopted from site-level AMF measurements. AOD data are adopted from instantaneous MODIS Aqua and Terra $3 \mathrm{~km}$ retrievals. Correlations are calculated for quasi-coincident AMF and MODIS data over summer noontime (June-August, 10:00-14:00 LT). The sampling number for each correlation is denoted in brackets. Significant $(p<0.05)$ correlation coefficients are bolded.

b For CA-Gro site, diffuse PAR observations of 2005-2009 have been discarded because of poor calibration, as documented on the AMF website.

(a) Simulated summer GPP

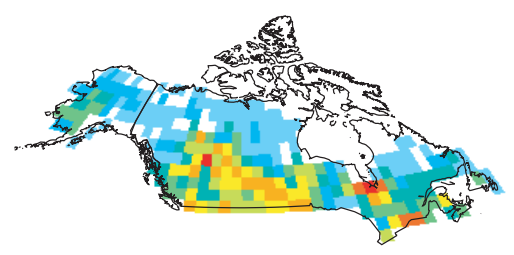

(c) Observed summer GPP
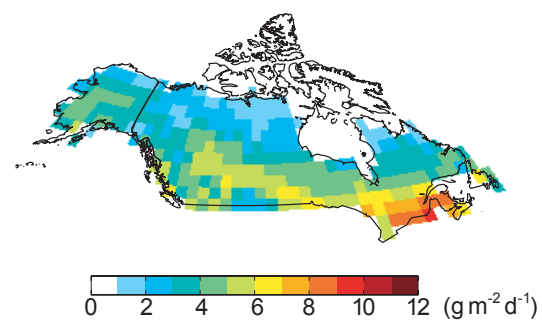

(e) GPP

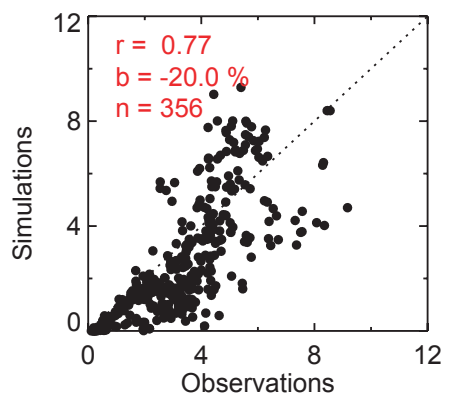

(b) Simulated summer AOD

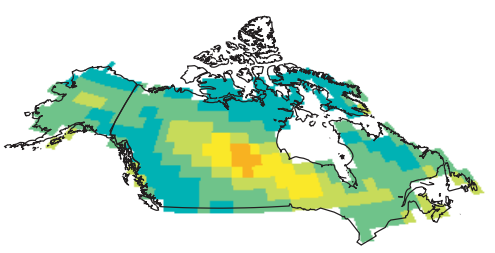

(d) Observed summer AOD

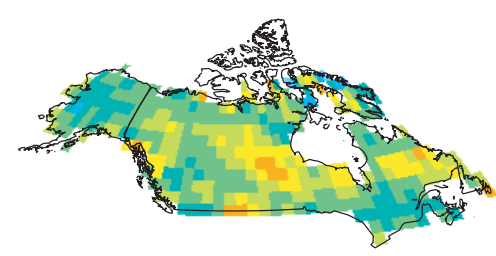

0.000 .050 .100 .150 .200 .250 .30

(f) AOD

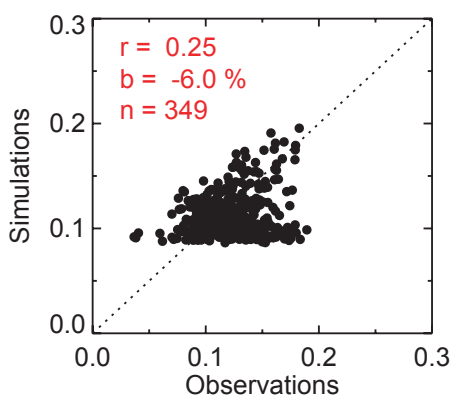

Figure 3. Evaluation of simulated summer (a) GPP and (b) AOD at $550 \mathrm{~nm}$ with (c, d) observations. Simulation results are from F10AERO (Table 1). Each point on the (e, f) scatter plot represents one grid square in boreal North America. The number of points $(n)$, correlation coefficient $(r)$, and relative bias $(b)$ for the evaluation are presented on the plot.

tent with surface observations (Fig. 4b), but the model overestimates the measured surface $\mathrm{O}_{3}$ by $22 \%$. The Canadian measurement sites are located near the southern boundary and as a result do not represent the average state over the vast boreal region at higher latitudes.

With the Sitch et al. (2007) scheme, the YIBs model simulates reasonable GPP responses to $\left[\mathrm{O}_{3}\right]$ in North America (Yue and Unger, 2014; Yue et al., 2016). Generally, damage to GPP increases with the enhancement of ambient $\left[\mathrm{O}_{3}\right]$, but with varied sensitivities for different plant species (see Fig. 6 of Yue and Unger, 2014). In response to the same level of $\left[\mathrm{O}_{3}\right]$, predicted $\mathrm{O}_{3}$ damages are higher for deciduous trees than those for needleleaf trees, consistent with observations from meta-analyses (Wittig et al., 2007). The model also reproduces observed light responses of GPP to diffuse radiation in boreal regions. With the site-level simulations, we evaluate the modeled GPP-PAR dif $_{\text {relationships at the hourly }}$ (instead of half-hourly) time step during summer. For 1342 
(a) Simulated summer MDA8 $\mathrm{O}_{3}$

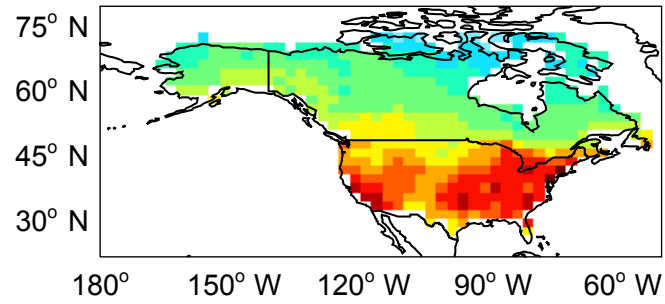

(b) Observed summer MDA8 $\mathrm{O}_{3}$
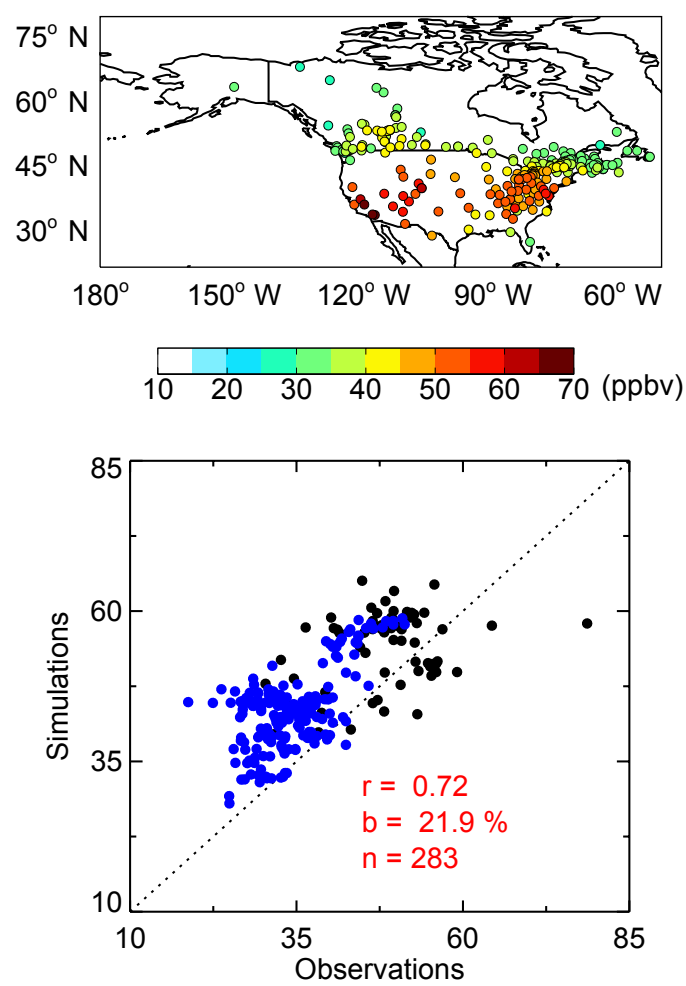

Figure 4. Evaluation of simulated summer surface maximum daily $8 \mathrm{~h}$ average $\left[\mathrm{O}_{3}\right]$ with observations for 2008-2012. Observations are collected from 81 US sites at the Clean Air Status and Trends Network (CASTNET) and 202 Canadian sites at the National Air Pollution Surveillance (NAPS) program. The number of points $(n)$, correlation coefficient $(r)$, and mean bias $(b)$ for the evaluation are presented on the plot. Values over Canada and Alaska are denoted with blue points.

pairs of GPP and PAR dif at the site CA-Gro, the observed correlation coefficient is 0.42 and regression slope is 0.011 , while the results for the simulation are 0.60 and 0.014 , respectively. At the site CA-Qfo, the observations yield a correlation coefficient of 0.46 and regression slope of 0.007 for 1777 pairs of GPP and PAR dif. The simulated correlation is 0.61 and the regression is 0.011 at the same site. The GPP sensitivity to PAR $_{\text {dif }}$ in the model is slightly higher than that of the available observations, likely because the latter are affected by additional non-meteorological abiotic factors. To remove the influences of compound factors other than radiation, we follow the approach of Mercado et al. (2009) to discriminate GPP responses to "diffuse" and "direct" components of PAR at the two sites (Fig. 5). The model successfully reproduces the observed GPP-to-PAR sensitivities. Increase in PAR boosts GPP, but the efficiency is much higher for diffuse light than that for direct light, suggesting that increase of diffuse radiation is a benefit for plant growth.

\subsection{Simulation of wildfire $\mathrm{O}_{3}$ and aerosols}

During 1980-2009, wildfire is observed to burn $2.76 \times 10^{6}$ ha and $156.3 \mathrm{Tg}$ DM every year over boreal North America. Similarly, the ensemble prediction with fire regression models estimates present-day area burned of $2.88 \times 10^{6} \mathrm{ha} \mathrm{yr}^{-1}$ and biomass burned of 160.2 $\mathrm{Tg} \mathrm{DM} \mathrm{yr}^{-1}$ (Yue et al., 2015). By the mid-century, area burned is projected to increase by $77 \%$ (to $5.10 \times 10^{6} \mathrm{ha} \mathrm{yr}^{-1}$ ) in boreal North America, mainly because of the higher temperature in future fire seasons. Consequently, biomass burned increases by $93 \%$ (to 308.6 $\mathrm{Tg} \mathrm{DM} \mathrm{yr}^{-1}$ ) because fuel consumption also increases by $9 \%$ on average in a drier climate (Yue et al., 2015). Enhanced fire emissions increase concentrations of surface $\mathrm{O}_{3}$ and column AOD, especially over Alaska and central Canada (Fig. 6). The maximum centers of air pollutants are collocated for $\mathrm{O}_{3}$ and AOD but with disproportional magnitudes, suggesting nonlinear conversion among fire emission species as well as the interactions with natural emission sources (e.g., lightning/soil $\mathrm{NO}_{x}$ and BVOC). On average, wildfire emissions contribute $7.1 \pm 3.1 \%(2.1 \pm 0.9 \mathrm{ppbv})$ to surface $\mathrm{O}_{3}$ and $25.7 \pm 2.4 \%(0.03 \pm 0.003)$ to AOD in the summer over boreal North America in the present day. By midcentury, these ratios increase significantly to $12.8 \pm 2.8 \%$ $(4.2 \pm 0.9 \mathrm{ppbv})$ for $\mathrm{O}_{3}$ and $36.7 \pm 2.0 \%(0.05 \pm 0.003)$ for AOD.

\subsection{Simulation of fire pollution impacts on NPP}

Surface $\mathrm{O}_{3}$, including both fire and non-fire emissions (Table 2), causes limited (1-2\%) damages to summer GPP in boreal North America (Fig. 7). The most significant damage is predicted over eastern US, where observed $\left[\mathrm{O}_{3}\right]$ is high over vast forest ecosystems (Fig. 4). In the western US, $\left[\mathrm{O}_{3}\right]$ is also high but the $\mathrm{O}_{3}$-induced GPP reduction is trivial because low stomatal conductance in the semiarid ecosystems limits $\mathrm{O}_{3}$ uptake there (Yue and Unger, 2014). Over boreal North America, dominant PFTs are ENF (accounting for $44 \%$ of total vegetation cover) and tundra (treated as shrubland, accounting for $41 \%$ of total vegetation cover). Both species have shown relatively high $\mathrm{O}_{3}$ tolerance with a damaging threshold of $40 \mathrm{ppbv}$ as calculated with Sitch's scheme (Yue and Unger, 2014). For boreal regions, the mean $\left[\mathrm{O}_{3}\right]$ of $28 \mathrm{ppbv}$ (Fig. 4a) is much lower than this damaging threshold, explaining why the excess $\mathrm{O}_{3}$ stomatal flux (the flux causing damages) is low there (Fig. 8). Statistics in Yue 
(a) Site CA-Gro

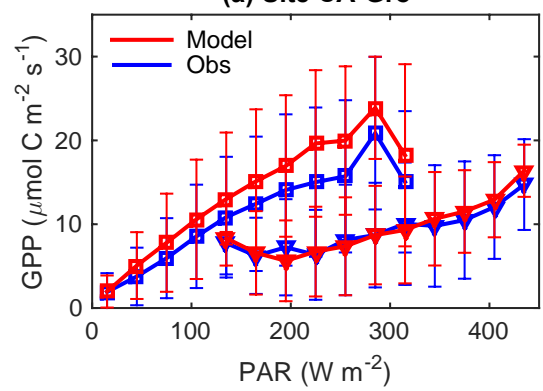

(b) Site CA-Qfo

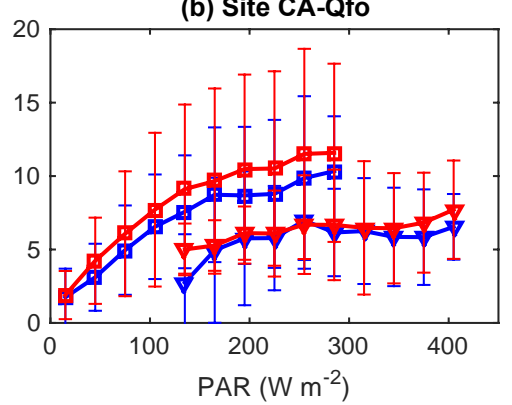

Figure 5. Observed (blue) and simulated (red) response of GPP to diffuse (square) and direct (triangle) PAR at boreal sites (a) CA-Gro (2004-2013) and (b) CA-Qfo (2004-2010). Observations and simulations are split into "diffuse" and "direct" conditions when the diffuse fraction is $>0.8$ and $<0.2$, respectively. Data points are then averaged over PAR bins of $30 \mathrm{~W} \mathrm{~m}^{-2}$ with error bars indicating 1 standard deviation of GPP for each bin.

(a) $\Delta \mathrm{O}_{3}$ by wildfire in 2010

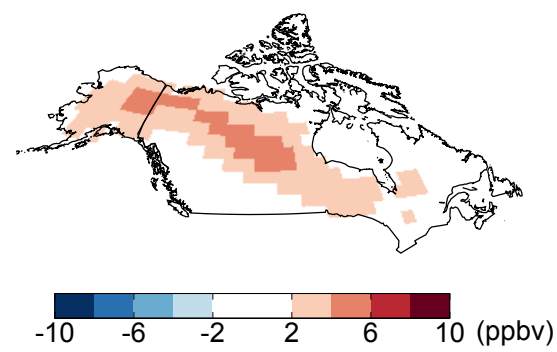

(c) $\triangle$ AOD by wildfire in 2010

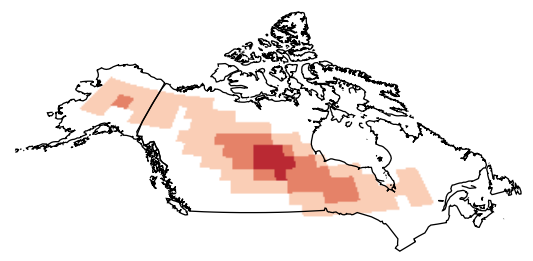

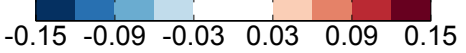

(b) $\Delta \mathrm{O}_{3}$ by wildfire in 2050

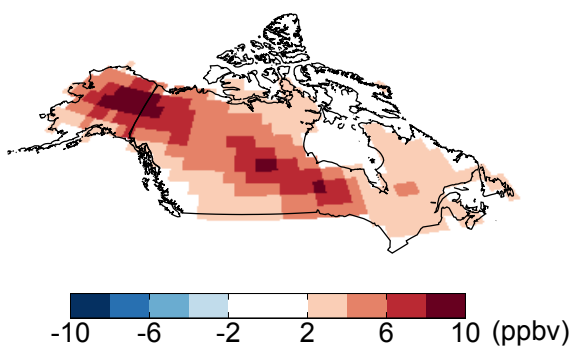

(d) $\triangle A O D$ by wildfire in 2050

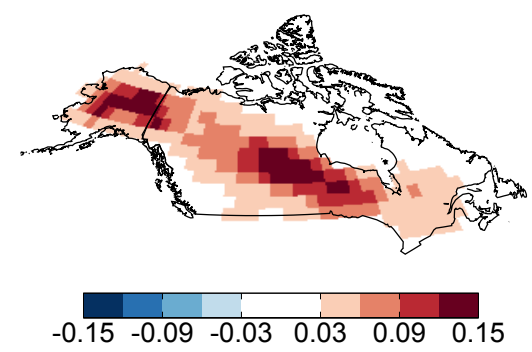

Figure 6. Changes in summer (a, b) $\left[\mathrm{O}_{3}\right]$ and $(\mathbf{c}, \mathbf{d}) \mathrm{AOD}$ at $550 \mathrm{~nm}$ induced by wildfire emissions in (a, c) the 2010s and (b, d) the 2050s over boreal North America. Only significant changes $(p<0.05)$ are shown.

et al. (2015) show that maximum daily $8 \mathrm{~h}$ average (MDA8) $\left[\mathrm{O}_{3}\right]$ with fire contributions can be higher than $40 \mathrm{ppbv}$ in Alaska and Canada. However, such episodes appear at the 95th percentile for present day and 90th percentile for midcentury, suggesting that $\mathrm{O}_{3}$ vegetation damage is rare in boreal North America and fire-induced $\mathrm{O}_{3}$ enhancement does not exacerbate such damages. Therefore, we do not consider $\mathrm{O}_{3}$ damage effects further.

Fire aerosols cause significant perturbations in shortwave radiation at surface (Fig. 9). The direct light is largely attenuated especially over Alaska and central Canada, where fire aerosols are most abundant (Fig. 6). In contrast, diffuse light widely increases due to particle scattering. In the present day, the average reduction of $5.6 \mathrm{~W} \mathrm{~m}^{-2}$ in the direct light component is in part offset by the enhancement of $2.6 \mathrm{~W} \mathrm{~m}^{-2}$ in the diffuse light component, leading to a net reduction of $3.0 \mathrm{~W} \mathrm{~m}^{-2}$ in solar radiation over boreal North America. By the mid-century, a stronger reduction of $9.5 \mathrm{~W} \mathrm{~m}^{-2}$ in direct light is accompanied by an increase of $4.0 \mathrm{~W} \mathrm{~m}^{-2}$ in diffuse light, resulting in a net reduction of $5.5 \mathrm{~W} \mathrm{~m}^{-2}$ in solar radiation. Fire-induced BC aerosols strongly absorb solar radiation in the atmospheric column (Fig. 10a, b). On average, fire aerosols absorb $1.5 \mathrm{~W} \mathrm{~m}^{-2}$ in the present day and $2.6 \mathrm{~W} \mathrm{~m}^{-2}$ by the mid-century. 
(a) Low ozone damage in 2010

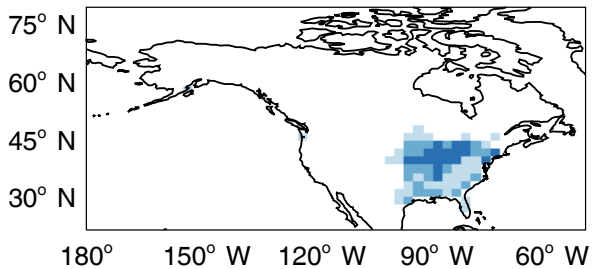

(c) High ozone damage in 2010

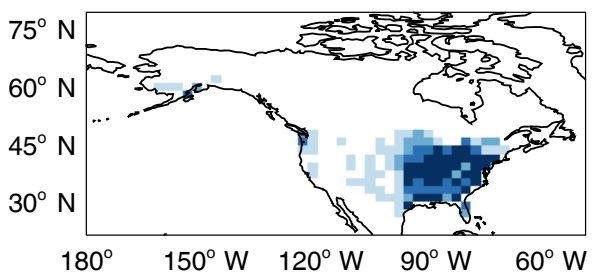

(b) Low ozone damage in 2050

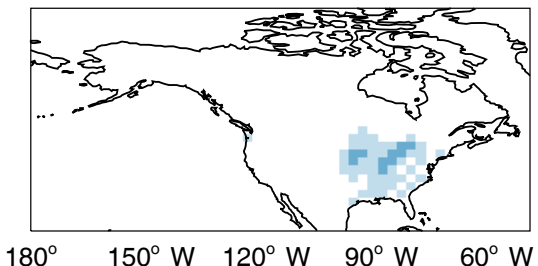

(d) High ozone damage in 2050

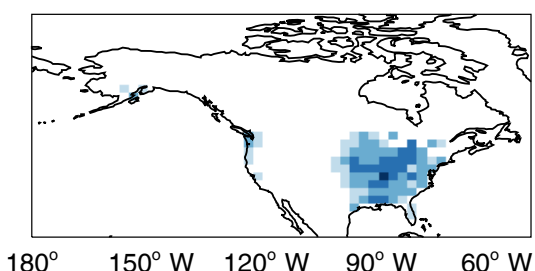

$180^{\circ} \quad 150^{\circ} \mathrm{W} \quad 120^{\circ} \mathrm{W} \quad 90^{\circ} \mathrm{W} \quad 60^{\circ} \mathrm{W}$

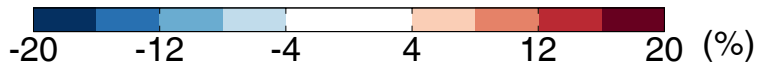

Figure 7. Simulated $\mathrm{O}_{3}$ damages to summer GPP in North America. Results shown are from simulations with (a, b) low and (c, d) high $\mathrm{O}_{3}$ sensitivities for $(\mathbf{a}, \mathbf{c}) 2010$ and $(\mathbf{b}, \mathbf{d})$ 2050. Simulated $\left[\mathrm{O}_{3}\right]$ includes contributions from both wildfire and non-fire emissions. Results for 2010 are derived as (F10O3/F10CTRL-1) $100 \%$. Results for 2050 are derived as (F50O3/F50CTRL-1) $\cdot 100 \%$.

(a) O3 stomatal flux in 2010

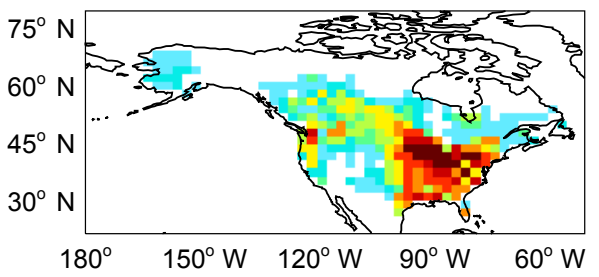

(b) O3 stomatal flux in 2050

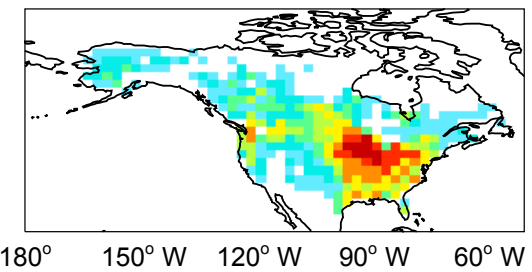

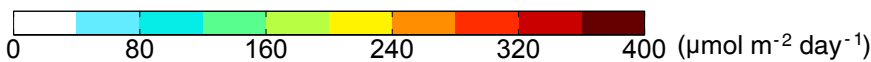

(c) Excess O3 stomatal flux in 2010

(d) Excess O3 stomatal flux in 2050
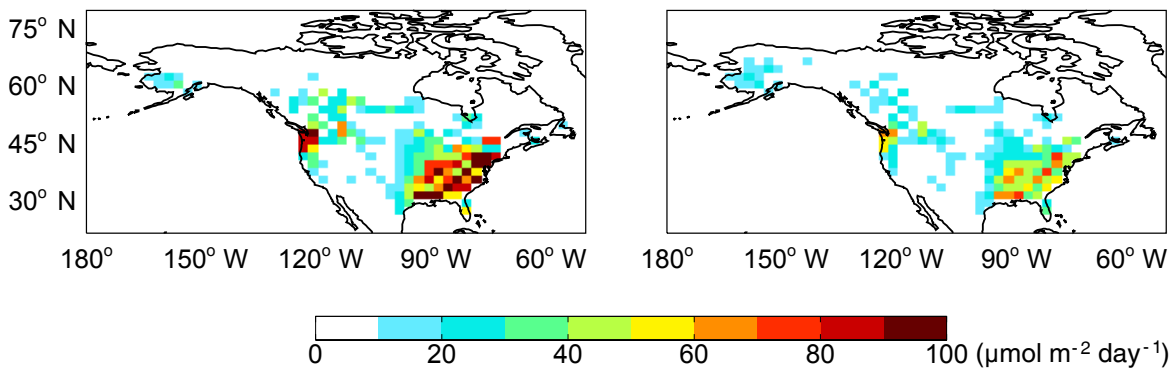

Figure 8. Simulated summertime $\mathrm{O}_{3}$ stomatal fluxes in boreal North America. Results shown are the (a, b) mean and (c, d) excess flux at (a, c) 2010 and $(\mathbf{b}, \mathbf{d}) 2050$. Simulated $\left[\mathrm{O}_{3}\right]$ includes contributions from both wildfire and non-fire emissions. Excess $\mathrm{O}_{3}$ stomatal flux is calculated as the difference between the stomatal flux and a PFT-specific threshold as defined in Sitch et al. (2007). 
(a) $\Delta$ SW_tot by fire aerosol in 2010

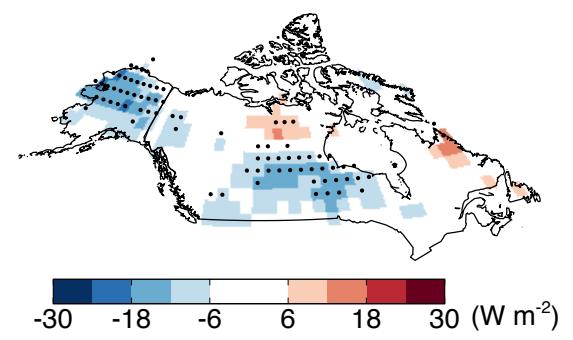

(c) $\Delta$ SW_dir by fire aerosol in 2010

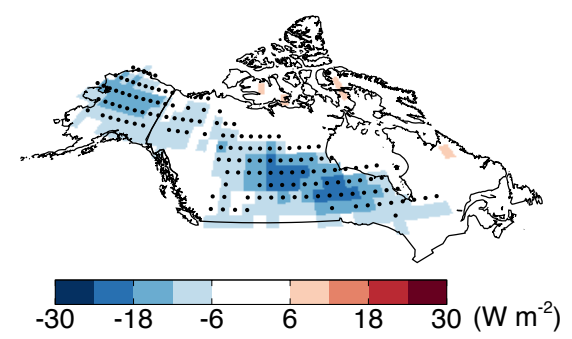

(e) $\Delta$ SW_dif by fire aerosol in 2010

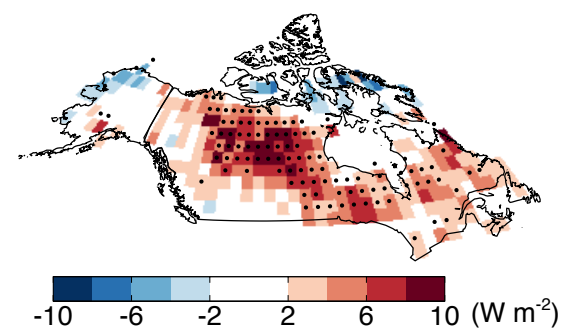

(b) $\Delta$ SW_tot by fire aerosol in 2050

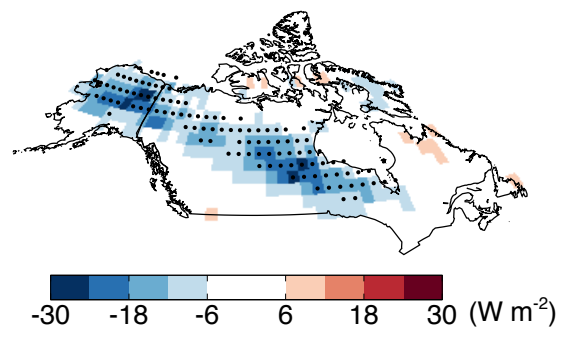

(d) $\Delta$ SW_dir by fire aerosol in 2050

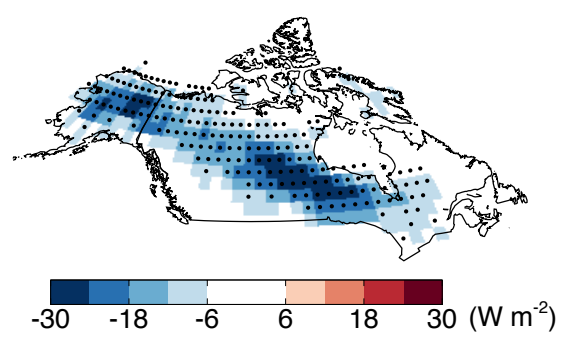

(f) $\Delta$ SW_dif by fire aerosol in 2050

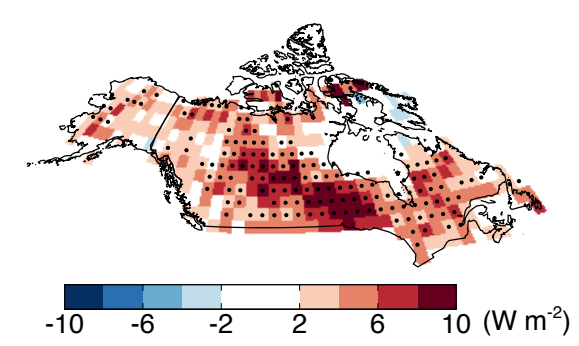

Figure 9. Changes in surface radiative fluxes induced by wildfire aerosols in boreal North America. Results shown are for the changes in summertime (June-August) (a, b) total, $(\mathbf{c}, \mathbf{d})$ direct, and $(\mathbf{e}, \mathbf{f})$ diffuse solar radiation at surface caused by aerosols from wildfire emissions at (a, c, e) present day and (b, d, f) mid-century. Significant changes $(p<0.05)$ are marked with black dots. Results for 2010 are calculated as F10AERO-F10CTRL. Results for 2050 are calculated as F50AERO-F50CTRL.

Atmospheric circulation patterns respond to the aerosolinduced radiative perturbations (Fig. 10c, d). Surface radiative cooling and atmospheric heating together increase air stability and induce anomalous subsidence. In the present day, such descending motion is confined to $55-68^{\circ} \mathrm{N}$, accompanied by a rising motion at $52-55^{\circ} \mathrm{N}$ (Fig. 10c). As a result, fire aerosols induce surface warming at higher latitudes but cooling at lower latitudes in boreal regions (Fig. 11a). Meanwhile, precipitation is inhibited by the subsidence in northwestern Canada but is promoted by the rising motion in the southwest (Fig. 11c). By the mid-century, the range of subsidence expands southward to $42^{\circ} \mathrm{N}$ (Fig. 10d) due to strengthened atmospheric heating (Fig. 10b). The downward convection of warm air offsets surface radiative cooling (Fig. 9b), leading to a significant warming in the southwest (Fig. 11b). The expanded subsidence further inhibits precip- itation in vast domain of Canada (Fig. 11d). Soil moisture is closely related to rainfall and as a result exhibits dipole changes (drier north and wetter south) in the present day (Fig. 11e) but widespread reductions (Fig. 11f) by the midcentury.

In response to the climatic effects of fire aerosols, boreal NPP shows distinct changes between the present day and mid-century (Fig. 12). Such changes in NPP are a consequence of changes in GPP and autotrophic respiration (Fig. S2). Variations in plant respiration resemble those of GPP, because higher photosynthesis leads to faster leaf and tissue development, resulting larger maintenance and growth respiration. In the $2010 \mathrm{~s}$, forest NPP increases by $5-15 \%$ in Alaska and southern Canada but decreases by $5-10 \%$ in northern and eastern Canada. This pattern of NPP changes $(\triangle \mathrm{NPP})$ is connected to the climatic effects of aerosols, 

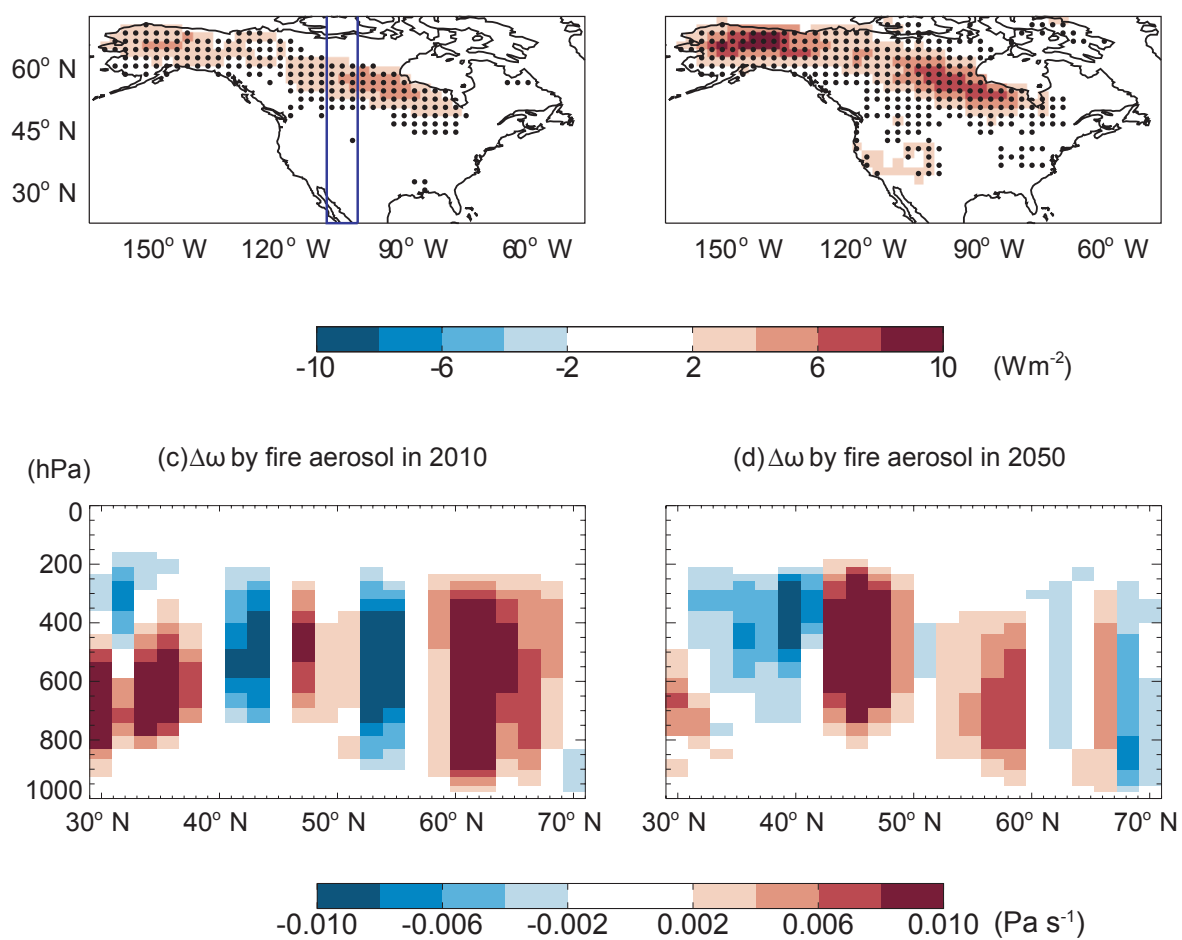

Figure 10. Predicted $(\mathbf{a}, \mathbf{b})$ absorption of shortwave radiation and $(\mathbf{c}, \mathbf{d})$ perturbations in vertical velocity by wildfire aerosols at (a, c) present day and (b, d) mid-century. The absorption of shortwave radiation is calculated as the differences of radiative perturbations between top of atmosphere and surface. Vertical velocity is calculated as the longitudinal average between 105 and $112.5^{\circ} \mathrm{W}$ (two blue lines in panel a). Positive (negative) values indicate descending (rising) motion. Results for the 2010s are calculated as F10AERO-F10CTRL. Results for the 2050s are calculated as F50AERO-F50CTRL. Significant changes $(p<0.05)$ in panel $(\mathbf{a}, \mathbf{b})$ are indicated as black points.

especially changes in soil moisture (Fig. 11). The correlation between $\triangle$ NPP (Fig. 12a) and changes in soil moisture (Fig. 11e) reaches $R=0.56(n=356)$, much higher than the values of $R=-0.11$ for temperature change (Fig. 11a) and $R=0.22$ for precipitation change (Fig. 11c). On the continental scale, the patchy responses of NPP offset each other. Since the dominant fraction of carbon uptake occurs in southern Canada (Fig. 3a), where positive NPP change is predicted (Fig. 12a), wildfire aerosols enhance the total NPP by $72 \mathrm{TgC}^{-1}$ in the present day (Table 5). In contrast, increased wildfire emissions in the 2050s inhibit precipitation (Fig. 11d) and decrease soil moisture in boreal North America (Fig. 11f), leading to widespread NPP reductions and a total NPP loss of $118 \mathrm{Tg} \mathrm{C} \mathrm{yr}^{-1}$ (Fig. 12b, Table 5).

\section{Discussion}

\subsection{Roles of aerosol climatic feedback}

The contrasting sign of NPP responses in the present day and mid-century are closely related to the aerosol-induced surface climatic feedback. Sensitivity experiments using offline YIBs model (Table 3) allowed assessment of the impacts

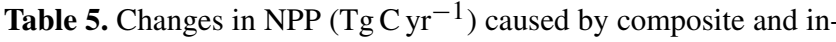
dividual climatic effects of fire aerosols.

\begin{tabular}{lrr}
\hline & $2010 \mathrm{~s}$ & $2050 \mathrm{~s}$ \\
\hline Online $^{\mathrm{a}}$ & 72 & -118 \\
Offline total $^{\mathrm{b}}$ & 126 & -97 \\
Temperature & 11 & -22 \\
Radiation & 8 & 14 \\
Soil moisture & 104 & -86
\end{tabular}

a Online results are calculated using the

ModelE2-YIBs model with F10AERO-F10CTRL for the 2010s and F50AERO-F50CTRL for the 2050s.

${ }^{\mathrm{b}}$ Offline results are calculated with the YIBs mode driven with individual or combined changes in temperature, radiation, and soil moisture.

of individual changes in the major meteorological drivers, including temperature, radiation (diffuse and direct), and soil moisture (Table 5). The offline simulations driven with changes in all three variables yield $\triangle \mathrm{NPP}$ of $126 \mathrm{Tg} \mathrm{C} \mathrm{yr}^{-1}$ for the 2010s and $-97 \mathrm{Tg} \mathrm{C} \mathrm{yr}^{-1}$ for the 2050s. These values are different from the online simulations, which predict

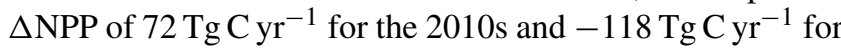
the 2050s. A lack of other aerosol-induced feedbacks in the 


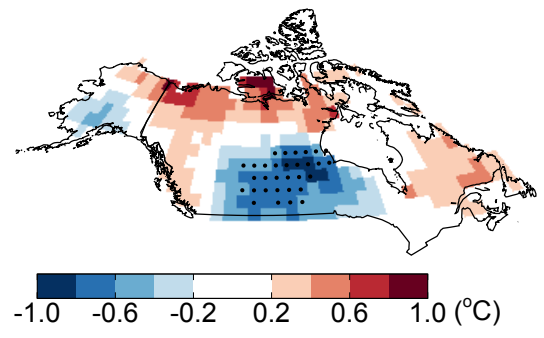

(c) $\triangle$ PREC by fire aerosol in 2010

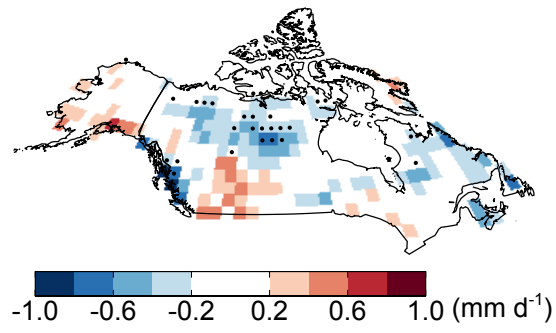

(e) $\triangle$ SOILW by fire aerosol in 2010

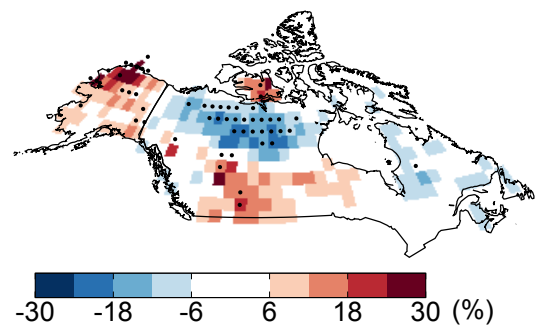

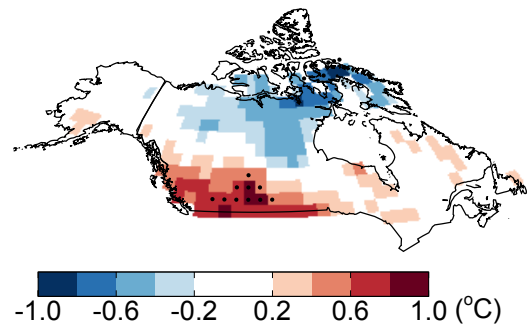

(d) $\triangle$ PREC by fire aerosol in 2050

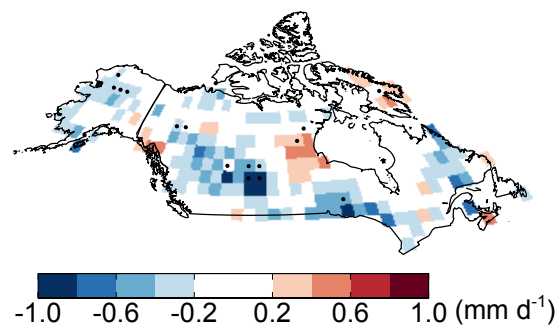

(f) $\Delta$ SOILW by fire aerosol in 2050

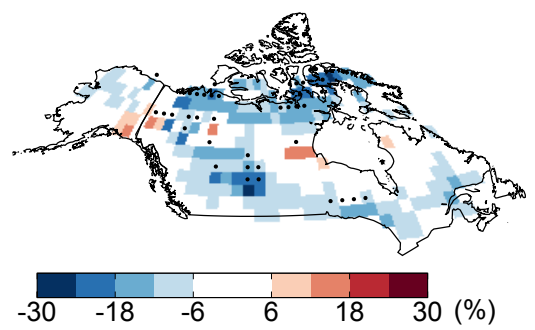

Figure 11. Predicted changes in summertime (a, b) surface air temperature, (c, d) precipitation, and (e, f) soil water content at surface caused by aerosols from wildfire emissions at $(\mathbf{a}, \mathbf{c}, \mathbf{e})$ present day and $(\mathbf{b}, \mathbf{d}, \mathbf{f})$ mid-century. Results for temperature and precipitation are shown as absolute changes. Results for soil water are shown as relative changes. Results for the 2010s are calculated as F10AERO-F10CTRL. Results for the 2050s are calculated as F50AERO-F50CTRL. Significant changes $(p<0.05)$ are marked with black dots.

(a) $\triangle$ NPP by fire aerosol in 2010
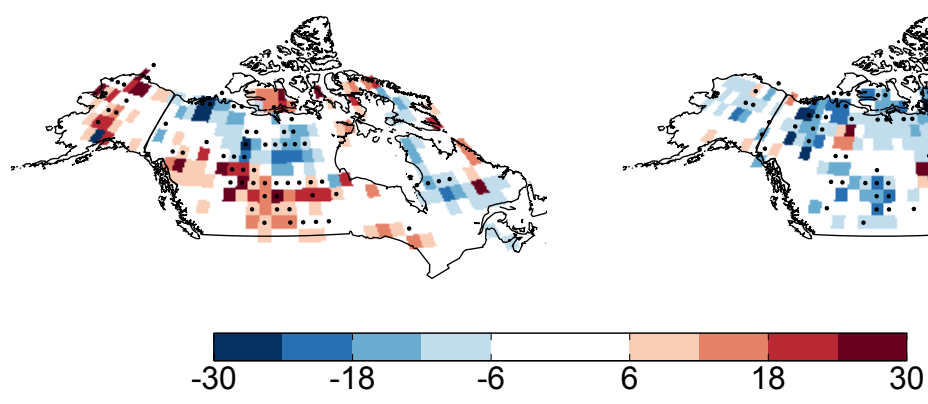

$(\%)$

(b) $\triangle$ NPP by fire aerosol in 2050

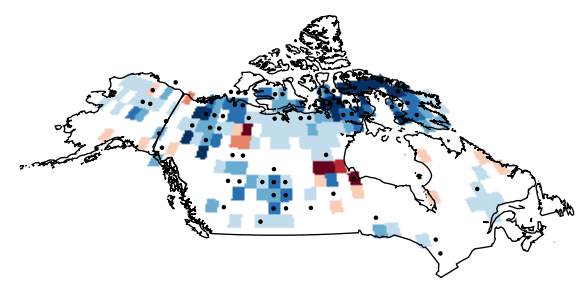

Figure 12. Predicted percentage changes in summer NPP caused by wildfire aerosols at (a) present day and (b) mid-century. Results for the 2010s are calculated as (F10AERO/F10CTRL-1) $100 \%$. Results for the 2050s are calculated as (F50AERO/F50CTRL-1) - 100\%. Significant changes $(p<0.05)$ are marked with black dots. 
offline model, for example changes in relative humidity, surface pressure, soil temperature, and turbulence momentum, may cause such discrepancy between the online and offline simulations. Seasonal analyses show that summertime $\triangle N P P$ is $99 \mathrm{Tg} \mathrm{C}$ at present day and $-95 \mathrm{Tg} \mathrm{C}$ at mid-century, dominating the NPP changes all through the year, because both wildfire emissions and ecosystem photosynthesis maximize in boreal summer.

Observations show that aerosols can promote plant photosynthesis through increasing diffuse radiation (Niyogi et al., 2004; Cirino et al., 2014; Strada et al., 2015). Our analyses with ground data also show positive correlations between

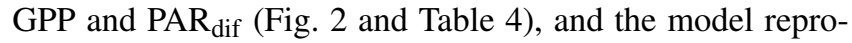
duces observed GPP responses to perturbations in direct and diffuse PAR (Fig. 5). Wildfire aerosols enhance diffuse radiation by $2.6 \mathrm{~W} \mathrm{~m}^{-2}(1.7 \%)$ at present day and $4.0 \mathrm{~W} \mathrm{~m}^{-2}$ $(2.3 \%)$ at mid-century in boreal North America (Fig. 9). With these changes, simulated NPP increases by $8 \mathrm{Tg} \mathrm{C} \mathrm{yr}^{-1}$ at the 2010s and $14 \mathrm{Tg} \mathrm{Cyr}^{-1}$ at the 2050s (Table 5). Near the two AMF sites (Fig. 2a), wildfires increase local AOD by 0.03 (Fig. 6c). Meanwhile, we estimate that summer average (00:00-24:00) GPP increases by $0.04 \mu \mathrm{mol} \mathrm{m}^{-2} \mathrm{~s}^{-1}$ in the same region due to aerosol diffuse fertilization effects (DFE) based on the results of Y10_PAR-Y10_CTRL. This change suggests a simulated GPP sensitivity of $1.2 \mu \mathrm{mol} \mathrm{m}^{-2} \mathrm{~s}^{-1}$ (22\%) per unit AOD. Observed GPP sensitivity to AOD at the two sites are $2.3(19 \%)$ and $4.5 \mu \mathrm{mol} \mathrm{m}^{-2} \mathrm{~s}^{-1}$ (58\%) per unit AOD (Fig. 2d, e). The absolute value of GPP sensitivity from simulations is much smaller than that of observations, because the former is for $24 \mathrm{~h}$ average while the latter is only for noontime (10:00-14:00). The relative change of $22 \%$ in YIBs model falls within the observed range of 19-58\%.

The estimated NPP changes of $8 \mathrm{Tg} \mathrm{Cyr}^{-1}$ by the radiative effects of boreal fire aerosols are much weaker than the enhancement of $78-156 \mathrm{Tg} \mathrm{C} \mathrm{yr}^{-1}$ by fires in the Amazon basin (Rap et al., 2015). There are at least two reasons for such a difference in the DFE between boreal and Amazon fire aerosols. First, wildfire emissions and associated impacts on radiation are much smaller in boreal regions. Wildfires in Alaska and Canada directly emit $68{\mathrm{Tg} \mathrm{C} \mathrm{yr}^{-1}}^{-1}$ at the 2010s, resulting in enhancement of summer AOD by $35 \%$ and diffuse radiation by $1.7 \%$. These boreal emissions are much smaller than the $\sim 240 \mathrm{Tg} \mathrm{Cyr}^{-1}$ in the Amazon basin (van der Werf et al., 2010), where fires enhance regional $\mathrm{PM}_{2.5}$ concentrations by $85 \%$ and diffuse radiation by $6.2 \%$ in dry seasons (Rap et al., 2015). Second, larger solar insolation at lower latitudes allows stronger DFE for the same unit change of diffuse radiation. In our prediction, most of the NPP changes occur at high latitudes in boreal regions (Fig. 12), where total insolation is not so abundant as that in the tropical areas. Consequently, the decline of direct radiation in boreal regions more likely converts the light availability of sunlit leaves from light saturation to light limitation, offsetting the benefit from enhanced diffuse radiation for shaded leaves. For this study, we do not find GPP reduc- tion by the decline of direct light at the two AMF sites (Table 4), possibly because these sites are located at middle latitudes $\left(<50^{\circ} \mathrm{N}\right)$. In the future, more observations at higher latitudes $\left(>55^{\circ} \mathrm{N}\right)$ are required to explore the sensitivity of GPP to AOD in light-limited conditions.

Simulations have shown that absorbing aerosols can cause regional drought by increasing air stability (Liu, 2005; Cook et al., 2009; Tosca et al., 2010). Our results confirm this tendency but with a varied range of hydrological responses depending on the magnitude of wildfire emissions (Figs. 11cf). Observations suggest that precipitation (and the associated soil moisture) is the dominant driver of the changes in GPP over North America, especially for the domain of cropland (Beer et al., 2010). Sensitivity experiments with offline YIBs model show that changes in soil moisture account for $82.5 \%$ of $\triangle \mathrm{NPP}$ at present day and $70.5 \%$ of $\triangle \mathrm{NPP}$ at mid-century (Table 5). These results suggest that aerosol-induced changes in soil water availability, instead of temperature and radiation, dominantly contribute to the changes of boreal NPP, consistent with observational and experimental results (Ma et al., 2012; Girardin et al., 2016; Chen et al., 2017).

\subsection{Limitations and uncertainties}

In this study, we examine the interactions among climate change, fire activity, air pollution, and ecosystem productivity. To reduce the complexity of the interactions, we focus on the most likely dominant feedback and thus main chain of events: climate $\rightarrow$ fire $\rightarrow$ pollution $\rightarrow$ biosphere (Fig. 1). However, our choice of feedback analysis does not mean that the interplay of other processes is unimportant. For example, climate-induced changes in vegetation cover and types can influence fire activity by alteration of fuel load and air pollution by BVOC emissions (climate $\rightarrow$ biosphere $\rightarrow$ fire/pollution). In addition, other feedbacks may amplify ecosystem responses but are not considered. For example, the drought caused by fire aerosols in the mid-century (Fig. 11) may help increase fire activity (fire $\rightarrow$ pollution $\rightarrow$ climate $\rightarrow$ fire). Furthermore, we apply fixed SSTs in the climate simulations because reliable ocean heat fluxes for the future world were not available. Many previous studies have investigated regional aerosol-climate feedbacks without ocean responses. For example, Cook et al. (2009) found that dustclimate-vegetation feedback promotes drought in US, with a climate model driven by prescribed SSTs. Similarly, Liu (2005) found fire aerosols enhance regional drought using a regional climate model, which even ignores the feedback between local climate and large-scale circulation. While we do concede that our experimental design is not a complete assessment of all known processes and feedbacks, within these limitations, this study for the first time quantifies the indirect impacts of wildfire on long-range ecosystem productivity under climate change.

We use the ensemble projected fire emissions from Yue et al. (2015). Area burned is predicted based on the simu- 
lated meteorology from multiple climate models. Such an approach may help reduce model uncertainties in climatic responses to $\mathrm{CO}_{2}$ changes (Collins et al., 2013; Kirtman et al., 2014) but cannot remove the possible biases in the selection of climate scenarios and fire models. All predictions in Yue et al. (2015) are performed under the IPCC A1B scenario. With two different scenarios, A2 of high emissions and B2 of low emissions, Balshi et al. (2009) showed that future area burned in boreal North America increases at a similar rate until the 2050s, after which area burned in A2 scenario increases much faster than that in B2 scenario. On average, boreal area burned in Balshi et al. (2009) increases by $\sim 160 \%$ during 2051-2060 compared with 2001-2010, which is much higher than the change of $66 \%$ in Yue et al. (2015). In contrast, Amiro et al. (2009) predicted that boreal area burned at the $2 \times \mathrm{CO}_{2}$ scenario increases only by $34 \%$ relative to the $1 \times \mathrm{CO}_{2}$ scenario. This ratio is only half of the estimate in Yue et al. (2015), which compared results between periods with $1.44 \times \mathrm{CO}_{2}$ and $1 \times \mathrm{CO}_{2}$. The discrepancies among these studies are more likely attributed to the differences in fire models. Although both Amiro et al. (2009) and Yue et al. (2015) developed fire weather regressions in boreal ecoregions, the former study did not include geopotential height at $500 \mathrm{hPa}$ and surface relative humidity as predictors, which make dominant contributions to area burned changes in the latter study. In contrast, Balshi et al. (2009) developed nonlinear regressions between area burned and climate on a grid scale, which helps retain extreme values at both the temporal and spatial domain. Compared to previous estimates, Yue et al. (2015) predicted median increases in future fire emissions over boreal North America.

We apply constant land cover and fuel load for both present day and mid-century, but we estimate an increase in fuel consumption due to changes in fuel moisture. Future projection of boreal fuel load is highly uncertain because of multiple contrasting influences. For example, using a dynamic global vegetation model (DGVM) and an ensemble of climate change projections, Heyder et al. (2011) predicted a large-scale dieback in boreal-temperate forests due to increased heat and drought stress in the coming decades. In contrast, projections using DGVMs show a widespread increase in vegetation carbon under the global warming scenario with $\mathrm{CO}_{2}$ fertilization of photosynthesis (Friend et al., 2014; Knorr et al., 2016). In addition, compound factors such as greenhouse gas mitigation (Kim et al., 2017), population change (Knorr et al., 2016), pine beetle outbreak (Kurz et al., 2008), and fire management (Doerr and Santin, 2016) may exert varied impacts on future vegetation and fuel load. Although we apply constant fuel load, we consider changes of fuel moisture because warmer climate states tend to dry fuel and increase fuel consumption (Flannigan et al., 2016). With constant fuel load but climate-driven fuel moisture, we calculate a $9 \%$ increase in boreal fuel consumption by the mid-century (Yue et al., 2015). Although such increment is higher than the prediction of $2-5 \%$ by Amiro et al. (2009) for a doubled- $\mathrm{CO}_{2}$ climate, the consumption-induced uncertainty for fire emission is likely limited because changes in area burned are much more profound.

Predicted surface $\left[\mathrm{O}_{3}\right]$ is much higher than observations over boreal North America (Fig. 4). This bias does not affect main conclusions of this study, because predicted $\mathrm{O}_{3}$ causes limited damages to boreal GPP even with the overestimated $\left[\mathrm{O}_{3}\right]$ (Fig. 7). The result confirms that fire-induced $\mathrm{O}_{3}$ vegetation damage is negligible in boreal North America. For aerosols, the model captures reasonable spatial pattern of AOD but with a background value of $\sim 0.1$ outside fire-prone regions, where the observed AOD is usually 0.1-0.2 (Fig. 3). This discrepancy may be related to the insufficient representations of physical and chemical processes in the model but may also result from the retrieval biases in MODIS data due to the poor surface conditions (Liu et al., 2005) and small AOD variations (Vachon et al., 2004) at high latitudes.

Simulated aerosol climatic effects depend on radiative and physical processes implemented in the climate model. We find that present-day boreal fire aerosols on average absorb $1.5 \mathrm{~W} \mathrm{~m}^{-2}$ in the atmosphere (Fig. 10), which is much smaller than the value of $20.5 \pm 9.3 \mathrm{~W} \mathrm{~m}^{-2}$ for fires in equatorial Asia (Tosca et al., 2010). This is because boreal fires enhance AOD only by 0.03 while tropical fires increase AOD by $\sim 0.4$. Previous modeling studies showed that fire plumes induce regional and downwind drought through enhanced atmospheric stability (Feingold et al., 2005; Tosca et al., 2010; Liu et al., 2014). Most of these results were based on the direct and/or semidirect radiative effects of fire aerosols. Inclusion of the indirect aerosol effect may further inhibit precipitation and amplify drought but may also introduce additional uncertainties for the simulations. The fire-drought interaction may promote fire activity, especially in a warmer climate. Ignoring this interaction may underestimate future area burned and the consequent emissions.

\subsection{Implications}

Inverse modeling studies have shown that the land ecosystems of boreal North America are carbon neutral in the present day, with the estimated land-to-air carbon flux from $-270 \pm 130$ to $300 \pm 500 \mathrm{Tg} \mathrm{Cyr}^{-1}$ (Gurney et al., 2002; Rödenbeck et al., 2003; Baker et al., 2006; Jacobson et al., 2007; Deng et al., 2014). Here, we reveal a missing land carbon source due to future wildfire pollution, taking into account full coupling among fire activity, climate change, air pollution, and the carbon cycle. Fire pollution aerosol increases boreal NPP by $72 \mathrm{Tg} \mathrm{Cyr}^{-1}$ in the present day, comparable to the direct carbon loss of $68 \mathrm{TgC}^{-1}$ from wildfire $\mathrm{CO}_{2}$ emissions (product of biomass burned and $\mathrm{CO}_{2}$ emission factors). By mid-century, increasing fire emissions instead cause a NPP reduction of $118 \mathrm{Tg} \mathrm{C} \mathrm{yr}^{-1}$ due to the amplified drought. Although NPP is not a direct indicator of the land carbon sink, reduction of NPP is always accompanied with the decline of net ecosystem ex- 
change and the enhanced carbon loss. In combination with the enhanced carbon emission of $130 \mathrm{Tg} \mathrm{C} \mathrm{yr}^{-1}$, future boreal wildfire presents an increasing threat to the regional carbon balance and global warming mitigation. Furthermore, the NPP reductions are mostly located in southern Canada, where cropland is the dominant ecosystem, newly exposing the future wildfire-related air pollution risk to food production.

Our analyses of fire pollution effects on boreal North American productivity may not be representative for other boreal ecosystems and/or on the global scale. There is substantial variability in plant species, topography, and climatology across different boreal regions. Such differences indicate distinct GPP sensitivities as well as fire characteristics. At lower latitudes, where anthropogenic pollution emissions are more abundant, ambient ozone concentrations may have exceeded damaging thresholds for most plant species. In those regions, additional ozone from a fire plume may cause more profound impacts on photosynthesis than our estimate for boreal North America. For example, Amazonian fire is predicted to reduce forest NPP by $230 \mathrm{TgC}^{-1}$ through the generation of surface ozone (Pacifico et al., 2015). Meanwhile, solar radiation is more abundant at lower latitudes, indicating more efficient increases in photosynthesis through aerosol DFE because the sunlit leaves receive saturated direct light in those regions. As shown in Beer et al. (2010), partial correlations between GPP and solar radiation are positive in boreal regions but negative over the subtropics and tropics, suggesting that light extinction by fire aerosols has contrasting impacts on plant photosynthesis in the high versus low latitudes. Further simulations and analyses are required to understand the net impacts of ozone and aerosols from biomass burning on the global carbon cycle.

Data availability. Data used in this study can be provided upon request to the corresponding author, $\mathrm{Xu}$ Yue (xuyueseas@gmail.com). Due to limited disk space, simulation results used for analyses will be deleted 1 year after the paper's publication.

\section{The Supplement related to this article is available online at https://doi.org/10.5194/acp-17-13699-2017- supplement.}

Competing interests. The authors declare that they have no conflict of interest.

Acknowledgements. Xu Yue acknowledges funding support from the National Key Research and Development Program of China (grant no. 2017YFA0603802), the National Basic Research Program of China (973 program, grant no. 2014CB441202), and the "Thousand Youth Talents Plan". Nadine Unger acknowledges funding support from the University of Exeter.

Edited by: Frank Dentener

Reviewed by: two anonymous referees

\section{References}

Alvarado, M. J., Logan, J. A., Mao, J., Apel, E., Riemer, D., Blake, D., Cohen, R. C., Min, K.-E., Perring, A. E., Browne, E. C., Wooldridge, P. J., Diskin, G. S., Sachse, G. W., Fuelberg, H., Sessions, W. R., Harrigan, D. L., Huey, G., Liao, J., Case-Hanks, A., Jimenez, J. L., Cubison, M. J., Vay, S. A., Weinheimer, A. J., Knapp, D. J., Montzka, D. D., Flocke, F. M., Pollack, I. B., Wennberg, P. O., Kurten, A., Crounse, J., Clair, J. M. St., Wisthaler, A., Mikoviny, T., Yantosca, R. M., Carouge, C. C., and Le Sager, P.: Nitrogen oxides and PAN in plumes from boreal fires during ARCTAS-B and their impact on ozone: an integrated analysis of aircraft and satellite observations, Atmos. Chem. Phys., 10, 9739-9760, https://doi.org/10.5194/acp10-9739-2010, 2010.

Amiro, B. D., Cantin, A., Flannigan, M. D., and de Groot, W. J.: Future emissions from Canadian boreal forest fires, Can. J. Forest Res., 39, 383-395, https://doi.org/10.1139/X08-154, 2009.

Andreae, M. O. and Merlet, P.: Emission of trace gases and aerosols from biomass burning, Global Biogeochem. Сy., 15, 955-966, 2001.

Atkin, O. K. and Tjoelker, M. G.: Thermal acclimation and the dynamic response of plant respiration to temperature, Trends Plant Sci., 8, 343-351, https://doi.org/10.1016/S1360-1385(03)001365, 2003.

Baker, D. F., Law, R. M., Gurney, K. R., Rayner, P., Peylin, P., Denning, A. S., Bousquet, P., Bruhwiler, L., Chen, Y. H., Ciais, P., Fung, I. Y., Heimann, M., John, J., Maki, T., Maksyutov, S., Masarie, K., Prather, M., Pak, B., Taguchi, S., and Zhu, Z.: TransCom 3 inversion intercomparison: Impact of transport model errors on the interannual variability of regional $\mathrm{CO}_{2}$ fluxes, 1988-2003, Global Biogeochem. Cy., 20, GB1002, https://doi.org/10.1029/2004gb002439, 2006.

Ball, J. T., Woodrow, I. E., and Berry, J. A.: A model predicting stomatal conductance and its contribution to the control of photosyn- thesis under different environmental conditions, in: Progress in Photosynthesis Research, edited by: Biggins, J., Nijhoff, Dordrecht, Netherlands, 110-112, 1987.

Balshi, M. S., McGuirez, A. D., Duffy, P., Flannigan, M., Walsh, J., and Melillo, J.: Assessing the response of area burned to changing climate in western boreal North America using a Multivariate Adaptive Regression Splines (MARS) approach, Glob. Change Biol., 15, 578-600, https://doi.org/10.1111/J.13652486.2008.01679.X, 2009.

Beer, C., Reichstein, M., Tomelleri, E., Ciais, P., Jung, M., Carvalhais, N., Rodenbeck, C., Arain, M. A., Baldocchi, D., Bonan, G. B., Bondeau, A., Cescatti, A., Lasslop, G., Lindroth, A., Lomas, M., Luyssaert, S., Margolis, H., Oleson, K. W., Roupsard, O., Veenendaal, E., Viovy, N., Williams, C., Woodward, F. I., and Papale, D.: Terrestrial Gross Carbon Dioxide Uptake: Global Distribution and Covariation with Climate, Science, 329, 834-838, https://doi.org/10.1126/Science.1184984, 2010. 
Bergeron, Y., Cyr, D., Girardin, M. P., and Carcaillet, C.: Will climate change drive 21 st century burn rates in Canadian boreal forest outside of its natural variability: collating global climate model experiments with sedimentary charcoal data, Int. J. Wildland Fire, 19, 1127-1139, https://doi.org/10.1071/Wf09092, 2010.

Bond-Lamberty, B., Peckham, S. D., Ahl, D. E., and Gower, S. T.: Fire as the dominant driver of central Canadian boreal forest carbon balance, Nature, 450, 89-92, https://doi.org/10.1038/Nature06272, 2007.

Chen, L., Huang, J.-G., Alam, S. A., Zhai, L., Dawson, A., Stadt, K. J., and Comeau, P. G.: Drought causes reduced growth of trembling aspen in western Canada, Glob. Change Biol., 23, 28872902, https://doi.org/10.1111/gcb.13595, 2017.

Cirino, G. G., Souza, R. A. F., Adams, D. K., and Artaxo, P.: The effect of atmospheric aerosol particles and clouds on net ecosystem exchange in the Amazon, Atmos. Chem. Phys., 14, 6523-6543, https://doi.org/10.5194/acp-14-6523-2014, 2014.

Cohan, D. S., Xu, J., Greenwald, R., Bergin, M. H., and Chameides, W. L.: Impact of atmospheric aerosol light scattering and absorption on terrestrial net primary productivity, Global Biogeochem. Cy., 16, 1090, https://doi.org/10.1029/2001gb001441, 2002.

Collins, M., Knutti, R., Arblaster, J., Dufresne, J.-L., Fichefet, T., Friedlingstein, P., Gao, X., Jr., W. J. G., Johns, T., Krinner, G., Shongwe, M., Tebaldi, C., Weaver, A. J., and Wehner, M.: Long-term Climate Change: Projections, Commitments and Irreversibility, in: Climate Change 2013: The Physical Science Basis. Contribution of Working Group I to the Fifth Assessment Report of the Intergovernmental Panel on Climate Change, edited by: Stocker, T. F., Qin, D., Plattner, G.-K., Tignor, M., Allen, S. K., Boschung, J., Nauels, A., Xia, Y., Bex, V., and Midgley, P. M., Cambridge University Press, Cambridge, United Kingdom and New York, NY, USA, 1029-1136, 2013.

Cook, B. I., Miller, R. L., and Seager, R.: Amplification of the North American "Dust Bowl" drought through human-induced land degradation, P. Natl. Acad. Sci. USA, 106, 4997-5001, https://doi.org/10.1073/pnas.0810200106, 2009.

Cox, P. M.: Description of the "TRIFFID” Dynamic Global Vegetation Model, Hadley Centre, Technical note 24, 2001.

de Groot, W. J., Flannigan, M. D., and Cantin, A. S.: Climate change impacts on future boreal fire regimes, Forest Ecol. Manag., 294, 35-44, https://doi.org/10.1016/j.foreco.2012.09.027, 2013.

Deng, F., Jones, D. B. A., Henze, D. K., Bousserez, N., Bowman, K. W., Fisher, J. B., Nassar, R., O’Dell, C., Wunch, D., Wennberg, P. O., Kort, E. A., Wofsy, S. C., Blumenstock, T., Deutscher, N. M., Griffith, D. W. T., Hase, F., Heikkinen, P., Sherlock, V., Strong, K., Sussmann, R., and Warneke, T.: Inferring regional sources and sinks of atmospheric $\mathrm{CO}_{2}$ from GOSAT $\mathrm{XCO}_{2}$ data, Atmos. Chem. Phys., 14, 3703-3727, https://doi.org/10.5194/acp14-3703-2014, 2014.

Doerr, S. H. and Santin, C.: Global trends in wildfire and its impacts: perceptions versus realities in a changing world, Philos. T. Roy. Soc. B, 371, https://doi.org/10.1098/rstb.2015.0345, 2016.

Duffy, P. A., Walsh, J. E., Graham, J. M., Mann, D. H., and Rupp, T. S.: Impacts of large-scale atmospheric-ocean variability on Alaskan fire season severity, Ecol. Appl., 15, 1317-1330, https://doi.org/10.1890/04-0739, 2005.

Farquhar, G. D., Caemmerer, S. V., and Berry, J. A.: A Biochemical-Model of Photosynthetic $\mathrm{CO}_{2}$ Assim- ilation in Leaves of $\mathrm{C}_{3}$ Species, Planta, 149, 78-90, https://doi.org/10.1007/Bf00386231, 1980.

Feingold, G., Jiang, H., and Harrington, J. Y.: On smoke suppression of clouds in Amazonia, Geophys. Res. Lett., 32, L02804, https://doi.org/10.1029/2004GL021369, 2005.

Flannigan, M. D., Logan, K. A., Amiro, B. D., Skinner, W. R., and Stocks, B. J.: Future area burned in Canada, Climatic Change, 72, 1-16, https://doi.org/10.1007/S10584-005-5935-Y, 2005.

Flannigan, M. D., Wotton, B. M., Marshall, G. A., Groot, W. J. d., Johnston, J., Jurko, N., and Cantin, A. S.: Fuel moisture sensitivity to temperature and precipitation: climate change implications, Climatic Change, 134, 59, https://doi.org/10.1007/s10584-0151521-0, 2016.

Flato, G., Marotzke, J., Abiodun, B., Braconnot, P., Chou, S. C., Collins, W., Cox, P., Driouech, F., Emori, S., Eyring, V., Forest, C., Gleckler, P., Guilyardi, E., Jakob, C., Kattsov, V., Reason, C., and Rummukainen, M.: Evaluation of Climate Models, in: Climate Change 2013: The Physical Science Basis. Contribution of Working Group I to the Fifth Assessment Report of the Intergovernmental Panel on Climate Change, edited by: Stocker, T. F., Qin, D., Plattner, G.-K., Tignor, M., Allen, S. K., Boschung, J., Nauels, A., Xia, Y., Bex, V., and Midgley, P. M., Cambridge University Press, Cambridge, United Kingdom and New York, NY, USA, 465-570, 2013.

Friend, A. D., Lucht, W., Rademacher, T. T., Keribin, R., Betts, R., Cadule, P., Ciais, P., Clark, D. B., Dankers, R., Falloon, P. D., Ito, A., Kahana, R., Kleidon, A., Lomas, M. R., Nishina, K., Ostberg, S., Pavlick, R., Peylin, P., Schaphoff, S., Vuichard, N., Warszawski, L., Wiltshire, A., and Woodward, F. I.: Carbon residence time dominates uncertainty in terrestrial vegetation responses to future climate and atmospheric $\mathrm{CO}_{2}$, P. Natl. Acad. Sci. USA, 111, 3280-3285, https://doi.org/10.1073/pnas.1222477110, 2014.

Gillett, N. P., Weaver, A. J., Zwiers, F. W., and Flannigan, M. D.: Detecting the effect of climate change on Canadian forest fires, Geophys. Res. Lett., 31, L18211, https://doi.org/10.1029/2004gl020876, 2004.

Girardin, M. P. and Mudelsee, M.: Past and future changes in Canadian boreal wildfire activity, Ecol. Appl., 18, 391-406, https://doi.org/10.1890/07-0747.1, 2008.

Girardin, M. P., Hogg, E. H., Bernier, P. Y., Kurz, W. A., Guo, X. J., and Cyr, G.: Negative impacts of high temperatures on growth of black spruce forests intensify with the anticipated climate warming, Glob. Change Biol., 22, 627-643, https://doi.org/10.1111/gcb.13072, 2016.

Gurney, K. R., Law, R. M., Denning, A. S., Rayner, P. J., Baker, D., Bousquet, P., Bruhwiler, L., Chen, Y. H., Ciais, P., Fan, S., Fung, I. Y., Gloor, M., Heimann, M., Higuchi, K., John, J., Maki, T., Maksyutov, S., Masarie, K., Peylin, P., Prather, M., Pak, B. C., Randerson, J., Sarmiento, J., Taguchi, S., Takahashi, T., and Yuen, C. W.: Towards robust regional estimates of $\mathrm{CO}_{2}$ sources and sinks using atmospheric transport models, Nature, 415, 626630, https://doi.org/10.1038/415626a, 2002.

Hansen, M. C., DeFries, R. S., Townshend, J. R. G., Carroll, M., Dimiceli, C., and Sohlberg, R. A.: Global Percent Tree Cover at a Spatial Resolution of 500 Meters: First Results of the MODIS Vegetation Continuous Fields Algorithm, Earth Interact., 7, 1-15, https://doi.org/10.1175/10873562(2003)007<0001:GPTCAA>2.0.CO;2, 2003. 
Heyder, U., Schaphoff, S., Gerten, D., and Lucht, W.: Risk of severe climate change impact on the terrestrial biosphere, Environ. Res. Lett., 6, 034036, https://doi.org/10.1088/1748-9326/6/3/034036, 2011.

Jacobson, A. R., Fletcher, S. E. M., Gruber, N., Sarmiento, J. L., and Gloor, M.: A joint atmosphere-ocean inversion for surface fluxes of carbon dioxide: 2. Regional results, Global Biogeochem. Cy., 21, GB1020, https://doi.org/10.1029/2006gb002703, 2007.

Jung, M., Reichstein, M., and Bondeau, A.: Towards global empirical upscaling of FLUXNET eddy covariance observations: validation of a model tree ensemble approach using a biosphere model, Biogeosciences, 6, 2001-2013, https://doi.org/10.5194/bg-6-2001-2009, 2009.

Kanniah, K. D., Beringer, J., North, P., and Hutley, L.: Control of atmospheric particles on diffuse radiation and terrestrial plant productivity: A review, Prog. Phys. Geog., 36, 209-237, https://doi.org/10.1177/0309133311434244, 2012.

Kasischke, E. S. and Turetsky, M. R.: Recent changes in the fire regime across the North American boreal region - Spatial and temporal patterns of burning across Canada and Alaska, Geophys. Res. Lett., 33, L09703, https://doi.org/10.1029/2006gl025677, 2006.

Keane, R. E., Agee, J. K., Fule, P., Keeley, J. E., Key, C., Kitchen, S. G., Miller, R., and Schulte, L. A.: Ecological effects of large fires on US landscapes: benefit or catastrophe?, Int. J. Wildland Fire, 17, 696-712, https://doi.org/10.1071/Wf07148, 2008.

Kim, J. B., Monier, E., Sohngen, B., Pitts, G. S., Drapek, R., McFarland, J., Ohrel, S., and Cole, J.: Assessing climate change impacts, benefits of mitigation, and uncertainties on major global forest regions under multiple socioeconomic and emissions scenarios, Environ. Res. Lett., 12, 045001, https://doi.org/10.1088/1748-9326/aa63fc, 2017.

Kirtman, B. P., Min, D., Infanti, J. M., Kinter, J. L., III, Paolino, D. A., Zhang, Q., van den Dool, H., Saha, S., Mendez, M. P., Becker, E., Peng, P., Tripp, P., Huang, J., DeWitt, D. G., Tippett, M. K., Barnston, A. G., Li, S., Rosati, A., Schubert, S. D., Rienecker, M., Suarez, M., Li, Z. E., Marshak, J., Lim, Y.-K., Tribbia, J., Pegion, K., Merryfield, W. J., Denis, B., and Wood, E. F.: The North American Multimodel Ensemble: Phase-1 Seasonalto-Interannual Prediction; Phase-2 toward Developing Intraseasonal Prediction, B. Am. Meteorol. Soc., 95, 585-601, 2014.

Knorr, W., Jiang, L., and Arneth, A.: Climate, $\mathrm{CO}_{2}$ and human population impacts on global wildfire emissions, Biogeosciences, 13, 267-282, https://doi.org/10.5194/bg-13-267-2016, 2016.

Kurz, W. A., Dymond, C. C., Stinson, G., Rampley, G. J., Neilson, E. T., Carroll, A. L., Ebata, T., and Safranyik, L.: Mountain pine beetle and forest carbon feedback to climate change, Nature, 452, 987-990, https://doi.org/10.1038/nature06777, 2008.

Levy, R. C., Mattoo, S., Munchak, L. A., Remer, L. A., Sayer, A. M., Patadia, F., and Hsu, N. C.: The Collection 6 MODIS aerosol products over land and ocean, Atmos. Meas. Tech., 6, 29893034, https://doi.org/10.5194/amt-6-2989-2013, 2013.

Liu, H. Q., Pinker, R. T., and Holben, B. N.: A global view of aerosols from merged transport models, satellite, and ground observations, J. Geophys. Res., 110, D10S15, https://doi.org/10.1029/2004JD004695, 2005.

Liu, J. C., Wilson, A., Mickley, L. J., Ebisu, K., Wang, Y., Sulprizio, M. P., Peng, R. D., Yue, X., Son, J.-Y., Anderson, G. B., Dominici, F., and Bell, M. L.: Wildfire- specific Fine Particulate Matter and Risk of Hospital Admissions in Urban and Rural Counties, Epidemiology, 28, 77-85, https://doi.org/10.1097/EDE.0000000000000556, 2017.

Liu, Y.: Enhancement of the 1988 northern U.S. drought due to wildfires, Geophys. Res. Lett., 32, L10806, https://doi.org/10.1029/2005GL022411, 2005.

Liu, Y., Goodrick, S., and Heilman, W.: Wildland fire emissions, carbon, and climate: Wildfire-climate interactions, Forest Ecol. Manag., 317, 80-96, https://doi.org/10.1016/j.foreco.2013.02.020, 2014.

Ma, Z. H., Peng, C. H., Zhu, Q. A., Chen, H., Yu, G. R., Li, W. Z., Zhou, X. L., Wang, W. F., and Zhang, W. H.: Regional drought-induced reduction in the biomass carbon sink of Canada's boreal forests, P. Natl. Acad. Sci. USA, 109, 2423 2427, https://doi.org/10.1073/pnas.1111576109, 2012.

McKenzie, D., Raymond, C. L., Kellogg, L. K. B., Norheim, R. A., Andreu, A. G., Bayard, A. C., Kopper, K. E., and Elman, E.: Mapping fuels at multiple scales: landscape application of the Fuel Characteristic Classification System, Can. J. Forest Res., 37, 2421-2437, https://doi.org/10.1139/X07-056, 2007.

Meehl, G. A., Covey, C., Delworth, T., Latif, M., McAvaney, B., Mitchell, J. F. B., Stouffer, R. J., and Taylor, K. E.: The WCRP CMIP3 multi-model dataset: A new era in climate change research, B. Am. Meteorol. Soc., 88, 1383-1394, https://doi.org/10.1175/BAMS-88-9-1383, 2007.

Mercado, L. M., Bellouin, N., Sitch, S., Boucher, O., Huntingford, C., Wild, M., and Cox, P. M.: Impact of changes in diffuse radiation on the global land carbon sink, Nature, 458, 1014-1017, https://doi.org/10.1038/nature07949, 2009.

Moritz, M. A., Parisien, M.-A., Batllori, E., Krawchuk, M. A., Dorn, J. V., Ganz, D. J., and Hayhoe, K.: Climate change and disruptions to global fire activity, Ecosphere, 3, 49, https://doi.org/10.1890/ES11-00345.1, 2012.

Morris, G. A., Hersey, S., Thompson, A. M., Pawson, S., Nielsen, J. E., Colarco, P. R., McMillan, W. W., Stohl, A., Turquety, S., Warner, J., Johnson, B. J., Kucsera, T. L., Larko, D. E., Oltmans, S. J., and Witte, J. C.: Alaskan and Canadian forest fires exacerbate ozone pollution over Houston, Texas, on 19 and 20 July 2004, J. Geophys. Res., 111, D24S03, https://doi.org/10.1029/2006jd007090, 2006.

Munchak, L. A., Levy, R. C., Mattoo, S., Remer, L. A., Holben, B. N., Schafer, J. S., Hostetler, C. A., and Ferrare, R. A.: MODIS $3 \mathrm{~km}$ aerosol product: applications over land in an urban/suburban region, Atmos. Meas. Tech., 6, 1747-1759, https://doi.org/10.5194/amt-6-1747-2013, 2013.

Nadeau, L. B., McRae, D. J., and Jin, J. Z.: Development of a national fuel-type map for Canada using fuzzy logic, Natural Resources Canada, Canadian Forest Service, Northern Forestry Centre, Edmonton, Alberta, Information Report NOR-X-406, 2005.

Nitschke, C. R. and Innes, J. L.: Climatic change and fire potential in South-Central British Columbia, Canada, Glob. Change Biol., 14, 841-855, https://doi.org/10.1111/j.1365-2486.2007.01517.x, 2008.

Niyogi, D., Chang, H.-I., Saxena, V. K., Holt, T., Alapaty, K., Booker, F., Chen, F., Davis, K. J., Holben, B., Matsui, T., Meyers, T., Oechel, W. C., Sr., R. A. P., Wells, R., Wilson, K., and Xue, Y.: Direct observations of the effects of aerosol loading on net ecosystem $\mathrm{CO}_{2}$ exchanges over different landscapes, Geophys. 
Res. Lett., 31, L20506, https://doi.org/10.1029/2004GL020915, 2004.

Oleson, K. W., Lawrence, D. M., Bonan, G. B., Flanne, M. G., Kluzek, E., Lawrence, P. J., Levis, S., Swenson, S. C., and Thornton, P. E.: Technical Description of version 4.0 of the Community Land Model (CLM), National Center for Atmospheric Research, Boulder, CONCAR/TN-478+STR, 2010.

Oliveira, P. H. F., Artaxo, P., Pires, C., de Lucca, S., Procópio, A., Holben, B., Schafer, J., Cardoso, L. F., Wofsy, S. C., and Rocha, H. R.: The effects of biomass burning aerosols and clouds on the $\mathrm{CO}_{2}$ flux in Amazonia, Tellus B, 59, 338-349, https://doi.org/10.1111/j.1600-0889.2007.00270.x, 2007.

Pacifico, F., Folberth, G. A., Sitch, S., Haywood, J. M., Rizzo, L. V., Malavelle, F. F., and Artaxo, P.: Biomass burning related ozone damage on vegetation over the Amazon forest: a model sensitivity study, Atmos. Chem. Phys., 15, 2791-2804, https://doi.org/10.5194/acp-15-2791-2015, 2015.

Randerson, J. T., Liu, H., Flanner, M. G., Chambers, S. D., Jin, Y., Hess, P. G., Pfister, G., Mack, M. C., Treseder, K. K., Welp, L. R., Chapin, F. S., Harden, J. W., Goulden, M. L., Lyons, E., Neff, J. C., Schuur, E. A. G., and Zender, C. S.: The impact of boreal forest fire on climate warming, Science, 314, 1130-1132, https://doi.org/10.1126/Science.1132075, 2006.

Rap, A., Spracklen, D. V., Mercado, L., Reddington, C. L., Haywood, J. M., Ellis, R. J., Phillips, O. L., Artaxo, P., Bonal, D., Coupe, N. R., and Butt, N.: Fires increase Amazon forest productivity through increases in diffuse radiation, Geophys. Res. Lett., 42, 4654-4662, https://doi.org/10.1002/2015g1063719, 2015.

Remer, L. A., Mattoo, S., Levy, R. C., and Munchak, L. A.: MODIS $3 \mathrm{~km}$ aerosol product: algorithm and global perspective, Atmos. Meas. Tech., 6, 1829-1844, https://doi.org/10.5194/amt-6-18292013, 2013.

Rödenbeck, C., Houweling, S., Gloor, M., and Heimann, M.: $\mathrm{CO}_{2}$ flux history 1982-2001 inferred from atmospheric data using a global inversion of atmospheric transport, Atmos. Chem. Phys., 3, 1919-1964, https://doi.org/10.5194/acp-3-1919-2003, 2003.

Schaefer, K., Collatz, G. J., Tans, P., Denning, A. S., Baker, I., Berry, J., Prihodko, L., Suits, N., and Philpott, A.: Combined Simple Biosphere/Carnegie-Ames-Stanford Approach terrestrial carbon cycle model, J. Geophys. Res., 113, G03034, https://doi.org/10.1029/2007jg000603, 2008.

Schmidt, G. A., Kelley, M., Nazarenko, L., Ruedy, R., Russell, G. L., Aleinov, I., Bauer, M., Bauer, S. E., Bhat, M. K., Bleck, R., Canuto, V., Chen, Y. H., Cheng, Y., Clune, T. L., Del Genio, A., de Fainchtein, R., Faluvegi, G., Hansen, J. E., Healy, R. J., Kiang, N. Y., Koch, D., Lacis, A. A., LeGrande, A. N., Lerner, J., Lo, K. K., Matthews, E. E., Menon, S., Miller, R. L., Oinas, V., Oloso, A. O., Perlwitz, J. P., Puma, M. J., Putman, W. M., Rind, D., Romanou, A., Sato, M., Shindell, D. T., Sun, S., Syed, R. A., Tausnev, N., Tsigaridis, K., Unger, N., Voulgarakis, A., Yao, M. S., and Zhang, J. L.: Configuration and assessment of the GISS ModelE2 contributions to the CMIP5 archive, Journal of Advances in Modeling Earth Systems, 6, 141-184, https://doi.org/10.1002/2013ms000265, 2014.

Shindell, D. T., Lamarque, J.-F., Schulz, M., Flanner, M., Jiao, C., Chin, M., Young, P. J., Lee, Y. H., Rotstayn, L., Mahowald, N., Milly, G., Faluvegi, G., Balkanski, Y., Collins, W. J., Conley, A. J., Dalsoren, S., Easter, R., Ghan, S., Horowitz, L., Liu, X., Myhre, G., Nagashima, T., Naik, V., Rumbold, S. T., Skeie, R.,
Sudo, K., Szopa, S., Takemura, T., Voulgarakis, A., Yoon, J.-H., and Lo, F.: Radiative forcing in the ACCMIP historical and future climate simulations, Atmos. Chem. Phys., 13, 2939-2974, https://doi.org/10.5194/acp-13-2939-2013, 2013a.

Shindell, D. T., Pechony, O., Voulgarakis, A., Faluvegi, G. , Nazarenko, L., Lamarque, J.-F., Bowman, K., Milly, G., Kovari, B., Ruedy, R., and Schmidt, G. A.: Interactive ozone and methane chemistry in GISS-E2 historical and future climate simulations, Atmos. Chem. Phys., 13, 2653-2689, https://doi.org/10.5194/acp-13-2653-2013, 2013 b.

Sitch, S., Cox, P. M., Collins, W. J., and Huntingford, C.: Indirect radiative forcing of climate change through ozone effects on the land-carbon sink, Nature, 448, 791-794, https://doi.org/10.1038/Nature06059, 2007.

Solomon, S., Qin, D., Manning, M., Chen, Z., Marquis, M., Averyt, K. B., Tignor, M., and Miller, H. L.: Climate Change 2007: Working Group I: The Physical Science Basis, Cambridge University Press, Cambridge, United Kingdom and New York, NY, USA, 2007.

Spitters, C. J. T.: Separating the Diffuse and Direct Component of Global Radiation and Its Implications for Modeling Canopy Photosynthesis. 2. Calculation of Canopy Photosynthesis, Agr. Forest Meteorol., 38, 231-242, https://doi.org/10.1016/01681923(86)90061-4, 1986.

Stocks, B. J., Mason, J. A., Todd, J. B., Bosch, E. M., Wotton, B. M., Amiro, B. D., Flannigan, M. D., Hirsch, K. G., Logan, K. A., Martell, D. L., and Skinner, W. R.: Large forest fires in Canada, 1959-1997, J. Geophys. Res., 108, 8149, https://doi.org/10.1029/2001jd000484, 2002.

Strada, S., Unger, N., and Yue, X.: Observed aerosolinduced radiative effect on plant productivity in the eastern United States, Atmos. Environ., 122, 463-476, https://doi.org/10.1016/j.atmosenv.2015.09.051, 2015.

Tosca, M. G., Randerson, J. T., Zender, C. S., Flanner, M. G., and Rasch, P. J.: Do biomass burning aerosols intensify drought in equatorial Asia during El Niño?, Atmos. Chem. Phys., 10, 35153528, https://doi.org/10.5194/acp-10-3515-2010, 2010.

Turetsky, M. R., Kane, E. S., Harden, J. W., Ottmar, R. D., Manies, K. L., Hoy, E., and Kasischke, E. S.: Recent acceleration of biomass burning and carbon losses in Alaskan forests and peatlands, Nat. Geosci., 4, 27-31, https://doi.org/10.1038/Ngeo1027, 2011.

Tymstra, C., Flannigan, M. D., Armitage, O. B., and Logan, K.: Impact of climate change on area burned in Alberta's boreal forest, Int. J. Wildland Fire, 16, 153-160, https://doi.org/10.1071/Wf06084, 2007.

Unger, N., Harper, K., Zheng, Y., Kiang, N. Y., Aleinov, I., Arneth, A., Schurgers, G., Amelynck, C., Goldstein, A., Guenther, A., Heinesch, B., Hewitt, C. N., Karl, T., Laffineur, Q., Langford, B., A. McKinney, K., Misztal, P., Potosnak, M., Rinne, J., Pressley, S., Schoon, N., and Serça, D.: Photosynthesis-dependent isoprene emission from leaf to planet in a global carbonchemistry-climate model, Atmos. Chem. Phys., 13, 1024310269, https://doi.org/10.5194/acp-13-10243-2013, 2013.

Vachon, F., Royer, A., Aube, M., Toubbe, B., O'Neill, N. T., and Teillet, P. M.: Remote sensing of aerosols over North American land surfaces from POLDER and MODIS measurements, Atmos. Environ., 38, 3501-3515, https://doi.org/10.1016/j.atmosenv.2004.01.046, 2004. 
Val Martin, M., Kahn, R. A., Logan, J. A., Paugam, R., Wooster, M., and Ichoku, C.: Space-based observational constraints for 1-D plume rise models, J. Geophys. Res., 117, D22204, https://doi.org/10.1029/2012JD018370, 2012.

van der Werf, G. R., Randerson, J. T., Giglio, L., Collatz, G. J., Mu, M., Kasibhatla, P. S., Morton, D. C., DeFries, R. S., Jin, Y., and van Leeuwen, T. T.: Global fire emissions and the contribution of deforestation, savanna, forest, agricultural, and peat fires (1997-2009), Atmos. Chem. Phys., 10, 1170711735,https://doi.org/10.5194/acp-10-11707-2010, 2010.

van Vuuren, D. P., Edmonds, J., Kainuma, M., Riahi, K., Thomson, A., Hibbard, K., Hurtt, G. C., Kram, T., Krey, V., Lamarque, J. F., Masui, T., Meinshausen, M., Nakicenovic, N., Smith, S. J., and Rose, S. K.: The representative concentration pathways: an overview, Climatic Change, 109, 5-31, https://doi.org/10.1007/s10584-011-0148-z, 2011.

Wang, X., Thompson, D. K., Marshall, G. A., Tymstra, C., Carr, R., and Flannigan, M. D.: Increasing frequency of extreme fire weather in Canada with climate change, Climatic Change, 130, 573-586, https://doi.org/10.1007/s10584-015-1375-5, 2015.

Wang, X. L., Parisien, M. A., Taylor, S. W., Perrakis, D. D. B., Little, J., and Flannigan, M. D.: Future burn probability in southcentral British Columbia, Int. J. Wildland Fire, 25, 200-212, https://doi.org/10.1071/Wf15091, 2016.

Wild, M., Folini, D., Schar, C., Loeb, N., Dutton, E. G., and Konig-Langlo, G.: The global energy balance from a surface perspective, Clim. Dynam., 40, 3107-3134, https://doi.org/10.1007/s00382-012-1569-8, 2013.

Wittig, V. E., Ainsworth, E. A., and Long, S. P.: To what extent do current and projected increases in surface ozone affect photosynthesis and stomatal conductance of trees? A meta-analytic review of the last 3 decades of experiments, Plant Cell Environ., 30, 1150-1162, https://doi.org/10.1111/J.1365-3040.2007.01717.X, 2007.

Wotawa, G. and Trainer, M.: The influence of Canadian forest fires on pollutant concentrations in the United States, Science, 288, 324-328, 2000.

Wotton, B. M., Nock, C. A., and Flannigan, M. D.: Forest fire occurrence and climate change in Canada, Int. J. Wildland Fire, 19, 253-271, https://doi.org/10.1071/Wf09002, 2010.
Yue, X. and Unger, N.: Ozone vegetation damage effects on gross primary productivity in the United States, Atmos. Chem. Phys., 14, 9137-9153, https://doi.org/10.5194/acp-149137-2014, 2014.

Yue, X. and Unger, N.: The Yale Interactive terrestrial Biosphere model version 1.0: description, evaluation and implementation into NASA GISS ModelE2, Geosci. Model Dev., 8, 2399-2417, https://doi.org/10.5194/gmd-8-2399-2015, 2015.

Yue, X., Mickley, L. J., Logan, J. A., and Kaplan, J. O.: Ensemble projections of wildfire activity and carbonaceous aerosol concentrations over the western United States in the mid-21st century, Atmos. Environ., 77, 767-780, https://doi.org/10.1016/J.Atmosenv.2013.06.003, 2013.

Yue, X., Mickley, L. J., Logan, J. A., Hudman, R. C., Martin, M. V., and Yantosca, R. M.: Impact of 2050 climate change on North American wildfire: consequences for ozone air quality, Atmos. Chem. Phys., 15, 10033-10055, https://doi.org/10.5194/acp-1510033-2015, 2015.

Yue, X., Keenan, T. F., Munger, W., and Unger, N.: Limited effect of ozone reductions on the 20-year photosynthesis trend at Harvard forest, Glob. Change Biol., 22, 3750-3759, https://doi.org/10.1111/gcb.13300, 2016.

Yue, X., Unger, N., Harper, K., Xia, X., Liao, H., Zhu, T., Xiao, J., Feng, Z., and Li, J.: Ozone and haze pollution weakens net primary productivity in China, Atmos. Chem. Phys., 17, 60736089, https://doi.org/10.5194/acp-17-6073-2017, 2017.

Zhao, Z., Kooperman, G. J., Pritchard, M. S., Russell, L. M., and Somerville, R. C. J.: Investigating impacts of forest fires in Alaska and western Canada on regional weather over the northeastern United States using CAM5 global simulations to constrain transport to a WRF-Chem regional domain, J. Geophys. Res., 119, 7515-7536, https://doi.org/10.1002/2013jd020973, 2014.

Zu, K., Tao, G., Long, C., Goodman, J., and Valberg, P.: Longrange fine particulate matter from the 2002 Quebec forest fires and daily mortality in Greater Boston and New York City, Air Quality Atmosphere and Health, 9, 213-221, https://doi.org/10.1007/s11869-015-0332-9, 2016. 